\title{
Economic and Financial Reform in El Salvador: Challenges and Opportunities to 2025
}

\author{
Ira Sohn \\ Montclair State University
}

This paper reviews El Salvador's vital statistics and recent economic and political events that impact the economy. El Salvador -- Central America's most densely populated though smallest country in land area -- has one of the highest homicide rates in the world in one of the world's most violent regions. Vulnerable to extreme weather-related events and external economic shocks such as the volatility in international oil prices, the country faces major challenges because of its appalling levels of crime, violence, and corruption. Using a framework that assesses the performance of a national economy that participates in today's globalized world, I identify the strengths and weaknesses of El Salvador's economy towards the end of enhancing the future performance of its economy.

Keywords: El Salvador, Economic and Financial Reform

\section{INTRODUCTION}

Latin America and the Caribbean experienced impressive growth over the decade from 2004 - 2013, with only a brief downturn in 2009 (United Nations, 2013). The favorable international economic environment until 2008 -- in particular the double digit growth of Gross Domestic Product (GDP) in China (and the resulting boom in international commodity prices) -- along with more responsible economic policies and/or improvements in the legal and tax environments for business in some countries in Latin America, i.e., Brazil, Chile, and Peru, resulted in higher economic growth and improved living standards in the Latin American region.

As a result of sluggish growth in the world economy in the aftermath of the Great Recession, i.e., global growth in GDP was less than 2.5\% p.a. from 2012-2016, along with major corruption scandals and governance issues in the large Latin American countries (Argentina, Brazil, Mexico, and Venezuela), regional economic growth since 2012 has been disappointing, approximately 1\% p.a. to 2017. Preliminary data estimate 2018 GDP growth for the region, after removing Venezuela, at only 1.6\% (Mander, 2018). As a result, in recent years Latin American countries have been oscillating between electing leftistpopulist governments and center-right governments, suggesting that voters believe the poor performance of their respective economies is more the result of institutional and structural failures than differences in the policies of the opposing parties. The results of the most recent elections in Colombia (June 2018), Mexico (July 2018), and Brazil (October 2018) lend support to this perception. In addition, the "21st century socialist" leaders in Nicaragua and Venezuela -- Daniel Ortega and Nicolás Maduro, respectively -- are facing increasing political and economic stress as a result of economic mismanagement and widespread corruption at the highest levels of government in their countries (Rathbone, 2018 ; Webber \& 
Rathbone, 2018). Finally, according to the International Monetary Fund global economic growth in 2017 was $3.8 \%$, the fastest pace since 2011 , and is expected to slow to $3.7 \%$ in 2018 , with annual GDP growth of $7 \%$ in India, $6.5 \%$ in China, $2.1 \%$ in the Euro area, and $2.9 \%$ in the United States (The Economist, 2018d).

The ongoing economic, political, and governance crises in Brazil -- the region's largest economy -warrant additional comment: GDP declined in both 2015 and 2016 by more than 3.6\%, turned slightly positive in 2017, and growth was only $1.5 \%$ in 2018. In 2015 and 2016 the country was mired in one of the worst recessions since the 1930 s with unemployment in excess of $9.0 \%$, annual inflation around $10 \%$, and a fiscal deficit above 8\% of GDP (United Nations, 2016; Jelmayer and Lewis, 2016). From 20162018 the country was also in the midst of political and constitutional crises with the removal of President Dilma Rousseff from office and the jailing of her predecessor Lula da Silva in April 2018. Rouseff's replacement, Michel Temer, who struggled with low single-digit approval figures and was weakened by investigations over corruption allegations, managed to survive politically until Jair Bolsonaro assumed office in January 2019.

This paper begins with a summary of El Salvador's vital statistics, and is followed by a review of the main political events -- particularly from the last half century -- that shaped some of the major institutions of the country, and the current -- both domestic and international -- political and economic environment that affects the performance of the Salvadoran economy that triggered some of the already implemented -as well as planned -- reforms that are discussed in Part 3. This section concludes with data that provide some measures of El Salvador's relative material wellbeing as compared with its neighboring countries in Central America. Part 2 provides a review of research regarding the "ingredients" judged to be important for a well-performing national economy that is participating in the wider global economy at the end of the second decade of the $21^{\text {st }}$ century. These "ingredients" are used in the next section to assess the current state of the Salvadoran economy -- both its strengths and weaknesses.

\section{PART 1. VITAL STATISTICS, A SUMMARY OF EL SALVADOR'S POLITICAL AND ECONOMIC HISTORY, AND SOME CURRENT COMPARATIVE MEASURES OF WELLBEING}

\section{Vital Statistics}

The Republic of El Salvador, administratively divided into 14 departments (comprising 262 municipalities) is bordered on the east and north-east by Honduras, on the north and north-west by Guatemala, and on the west and south by a $300 \mathrm{~km}$ shoreline of the Pacific Ocean, whose Gulf of Fonseca it shares with Honduras and Nicaragua. El Salvador is the only Central America country without a Caribbean coastline. With the smallest land area in Central America (and continental America) -- about 21,000 square $\mathrm{km}$-- El Salvador is slightly smaller than the US state of New Jersey.

El Salvador stretches about $270 \mathrm{~km}$ east-west and since it extends only $142 \mathrm{~km}$ north-south, the country lies within the narrow latitude band of 13-15 degrees north of the equator. In mid-2017, according to the World Bank, El Salvador's population was approximately 6.4 million people and its population growth rate in 2017 was estimated at only $0.25 \%$ per annum (p.a.), about one-quarter the Latin America average of $1.02 \%$ p.a. (Central Intelligence Agency (CIA), 2018). In 2017, the country registered a net out-migration rate of 8 per 1000 of population, among the highest in the world. Over $1 \mathrm{~m}$ people fled El Salvador during the civil war (1980-92) and sought asylum, mostly in the US. However, 98\% of the asylum applications were denied, so most Salvadorans stayed illegally. Today approximately $2 \mathrm{~m}$ Salvadorans reside abroad -- about $30 \%$ of the population -- most living (unauthorized) in the US. Annual remittances to El Salvador -- mostly from the US -- total around \$5bn, about 17\% of El Salvador's GDP, and are the second largest source of external income after exports (Jordan, 2018; CIA, 2018). Today, because of the unrelenting gang-related violence, 250 Salvadorans leave the country every day (Palumbo \& Ahmed, 2018).

Life expectancy at birth in 2017 was reported at approximately 75 years, about five years less than in the US, and the infant mortality rate in El Salvador was 16.8 per 1000 live births, about triple the US 
ratio. In 2018 about $70 \%$ of Salvadorans lived in urban areas, below the $82 \%$ US rate. The country's ethnic breakdown is $86.3 \%$ mestizo (mixed Amerindian and white), $12.7 \%$ white, $0.2 \%$ Amerindian, $0.1 \%$ black, and $0.6 \%$ other. El Salvador registers greater than $88 \%$ literacy for those 15 years and older, and in 2014 the country spent $3.4 \%$ of its GDP on education, about $70 \%$ of the US rate. The World Bank classifies El Salvador as an upper middle-income country, with per capita GDP in 2017 estimated at US $\$ 8,900$ on a purchasing power parity (ppp) basis (CIA, 2018).

Turning to the composition of GDP in 2017, agriculture accounted for $11 \%$ of GDP (but employed $21 \%$ of the approximate $2.8 \mathrm{~m}$ people in the labor force); industry for $25 \%$ of GDP (and $20 \%$ of the labor force); and services for approximately 58\% of GDP. In 2017, Gross Fixed Capital Formation as a percentage of GDP was reported at $14.5 \%$, the lowest reported percentage in the Latin America and Caribbean region, including increasingly dysfunctional Venezuela (United Nations, 2017). El Salvador's exports are comprised mostly of off-shore assembled manufactured products, as well as traditional exports such as sugar and coffee, and almost half of the country's exports are shipped to the US.

\section{A Brief Summary of El Salvador's Political and Economic History: 1522-2018}

At about the same time that the smallpox epidemic was devastating the indigenous population of Mesoamérica -- roughly equivalent to today's Central America and southern half of today's Mexico -the first visit by Spaniards to what is now known as El Salvador was made by the Spanish admiral, Andrés Niño, in 1522. Within two years, after participating in the conquest of Mexico, Spanish conquistadors led by Pedro de Alvarado and his brother Gonzalo crossed into today's El Salvador from the present day Guatemala in search of treasure as they had done in Mexico and Guatemala. They met stubborn resistance from the indigenous population for about ten years before succeeding to establish a permanent settlement in the garrison town of San Miguel in 1532. During the colonial period, El Salvador was incorporated into the Kingdom of Guatemala, part of the Spanish empire in the New World, that was created in 1609 and continued for more than two centuries.

The Kingdom of Guatemala was established to deal with foreign threats to the area from the Caribbean, with Spain granting the area autonomy in administrative and military matters. After this administrative division was terminated in September 1821 with the Act of Independence of Central America, El Salvador joined Costa Rica, Guatemala, Honduras, and Nicaragua in a union called the Federal Republic of Central America, which dissolved in 1841. El Salvador maintained its own government until 1896, when it joined with Honduras and Nicaragua to form the short-lived Greater Republic of Central America, which ended two years later.

From the late 19th century until the middle of the 20th century El Salvador was governed by a succession of presidents from a powerful oligarchy, whose families had vast land holdings. As the world market for indigo -- the most important crop during the colonial period -- declined because of the introduction of chemical dyes in mid-century, these powerful oligarchs moved into a new cash crop, coffee, which by the early 20th century accounted for $90 \%$ of El Salvador's export revenue. "Las catorce familias" ("the fourteen families") constituted the oligarchy that controlled the levers of political and economic power in El Salvador over this interval: most of the land and wealth, the national legislature, the presidency, and the constitution, as well as the administrative machinery of the 14 regional departments. In addition to promoting coffee as a cash crop, the Salvadoran oligarchy developed transport infrastructure (railroads and port facilities) to support the coffee trade, eliminated the communal landholdings of the campesinos to facilitate more efficient coffee production, and were successful in passing anti-vagrancy laws that would ensure a reliable and low-cost labor force from the displaced peasants and rural residents for their rapidly expanding coffee plantations.

Not surprisingly, the concentration of economic and political power in the hands of this privileged oligarchy triggered resistance from the indigenous population that resulted in political repression of the landless campesinos, and spawned authoritarian rule and periodic peasant uprisings, most notably the 1932 uprising following the military coup by Gen. Maximiliano Hernández Martínez, whose rise to power, in part, was propelled by the external shock of depressed international coffee prices that had severe economic consequences for El Salvador in light of the dominant role of coffee in the economy. 
After days of protests, the government retaliated with what is commonly referred to as La Matanza (the "slaughter"). Approximately 40,000 indigenous people and political opponents were murdered, imprisoned or exiled.

From the 1930s to the 1970s successive authoritative Salvadoran governments operated under the guise of democratic rule, including holding periodic presidential elections -- that were seldom fair and free -- and instituting limited reforms. However, political repression of the bulk of the increasingly impoverished population and ensuring the economic and political power of the oligarchy through their presidential appointees were the real objectives of the elite. In fact, until 1980, all but one Salvadoran president was an army officer.

With the continuing repression of the land-starved campesinos, many of them emigrated to neighboring -- and much less densely-populated -- Honduras, establishing themselves as squatters on unused land that generated friction between the two neighboring countries. The simmering resentments came to a boil during an 18-day interval in June 1969 that coincided with three football games between the two countries for a coveted spot in the 1970 World Cup to be held in Mexico. All three games between the two teams were marred by violence, and the same day as the decisive game was played (and won by El Salvador, in extra time), El Salvador dissolved all diplomatic ties with Honduras, stating that "the government of Honduras has not taken any effective measures to punish these crimes which constitute genocide, nor has it given assurances of indemnification or reparations for the damages caused to Salvadorans". On July 14, the Salvadoran Air Force attacked targets inside Honduras, which caught the better equipped Honduran air force off guard. The larger Salvadoran army then invaded Honduras.

The Organization of American States (OAS) quickly called for a ceasefire, and on July 18, after four days of fighting, "the 1969 Football War", or "the 100-Hours War", ended, and on August 2, E1 Salvador withdrew its troops. However, the brief hostilities resulted in over 2,000 casualties on each side, with some 300,000 Salvadorans displaced, many of whom were forcibly expelled or fled to their home country, beaten and brutalized.

In the aftermath of the Football War, El Salvador continued to endure chronic political and economic instability characterized by coups, revolts, and a succession of authoritarian rulers. Predictably, the persistent socioeconomic inequality and civil unrest culminated in the devastating Salvadoran Civil War (1980-1992), which was fought between the military-led government and a coalition of left-wing guerrilla groups. Though tensions between the right and left in Salvadoran society were simmering for decades, the immediate trigger for the war was a right-wing backlash against the removal of a military dictator by reformist officers in 1979 (Roberts, 2017).

The broad-based coalition of left-wing groups included various elements from society who were fighting for the right to unionize, agrarian reform, better wages, accessible health care and freedom of expression. They included middle, high-school, and college students, farmers, and workers. On March 24, 1980 Monsignor Romero, the Archbishop of San Salvador, who repeatedly denounced injustices and massacres committed against civilians by government forces and was considered "the voice of the voiceless", was assassinated by a death squad while saying Mass. Subsequently, El Salvador descended into outright civil war between the military/oligarchy alliance and the above-mentioned groups who were aligned with the major guerrilla factions of El Salvador that formed the Farabundo Martí National Liberation Front, or FMLN. (Almost 40 years later, in October 2018, the slain Archbishop was canonized by Pope Francis (Rocca, 2018)).

As this period coincided with the waning years of the Cold War, unsurprisingly, the United States supported the military junta and the Soviet Union was allied with the left-wing guerrilla groups, with the US allocating approximately $\$ 4$ billion over the course of the war to defeat the rebels (Roberts, 2017). An unknown number of people "disappeared" during the 12-year conflict conflict, and the United Nations reported that more than 75,000 were killed, approximately $1.5 \%$ of the population. On January 16,1992 , the government of El Salvador and the FMLN -- represented by the commanders of the five guerrilla groups -- signed peace agreements brokered by the UN ending the civil war.

Following the signing of the Chapultepec Peace Accords, as the peace agreement was called, the difficult task of national reconciliation began to the end of rebuilding a country whose infrastructure was 
in ruins, the majority of the population was mired in poverty, and hundreds of thousands of Salvadorans had left -- and were continuing to leave -- the country for the US after 12 years of civil war (Hidalgo, 2009). The first order of business was to rein in the power of the military. To that end, "the constitution was amended to prohibit the military from playing an internal security role except under extraordinary circumstances. Demobilization of Salvadoran military forces generally proceeded on schedule throughout the process. The Treasury Police, National Guard, and National Police were abolished, and military intelligence functions were transferred to civilian control. By 1993 the military had cut personnel from a war-time high of 63,000 to the level of 32,000 required by the peace accords, and by 1999 the strength of the armed forces stood at less than 15,000, including uniformed and non-uniformed personnel. A purge of military officers accused of human rights abuses and corruption was completed in 1993. The military's new doctrine, professionalism, and complete withdrawal from political and economic affairs leave it one of the most respected institutions in El Salvador" (El Salvador, 2018). In addition, more than 35,000 eligible beneficiaries from among the former guerrillas and soldiers who fought in the war received land under the peace accord's mandated land-transfer program, which ended in January 1997. The majority of them also received agricultural credits.

Also, the government agreed to submit to the recommendations of a Commission on the Truth for El Salvador (Comisión de la Verdad Para El Salvador), that was overseen by the United Nations. The commission was charged to "investigate serious acts of violence occurring since 1980, and the nature and effects of the violence, and ... recommend methods of promoting national reconciliation." In 1993 the Commission delivered its findings reporting human rights violations on both sides of the conflict. Five days later the Salvadoran legislature passed an amnesty law, which has since been rescinded, for all acts of violence during the period.

From 1989 to 2009, Salvadorans elected four successive presidents from the center-right ARENA party which, following the civil war (1992), implemented a successful program of economic liberalization that included the privatization of state enterprises, deregulation, trade and financial liberalization, privatization of the pension system, and the adoption of the US dollar as its official currency (Hidalgo, 2009). (More about this below). From 1992 to 2009, the economy never slipped into recession and GDP was above $2 \%$ growth in every year but three. (Please see Part 3, below). Because of corruption allegations in the ARENA party, in 2009 Salvadorans elected a former journalist and television personality, Mauricio Funes, the candidate from the FMLN party -- that was formed by leaders of the Marxist guerrilla factions -- as president, and Salvador Sánchez Cerén as Vice President. This was the first victory for a leftist party candidate in El Salvador's history, and it is particularly noteworthy since Sánchez Cerén was a former guerrilla leader, and served as president of El Salvador until early 2019.

Since the FMLN took power (which coincided with the Great Recession (2009) when the economy declined by 3.3\%), El Salvador has been trapped in an orbit of approximately 2\% annual GDP growth. (More about this below). Because of official corruption and government policies that mandated large financial subsidies, in April 2012 the International Monetary Fund (IMF) suspended a \$750m loan to the government.

To be sure, while corruption levels are still very high, arguably, today, the principal impediment to higher economic growth and improved living standards in El Salvador is the extreme level of gang-related violence and extortion that is simultaneously deterring foreign direct investment and promoting large scale emigration by young Salvadorans from all levels of society because of the absence of personal security and the lack of economic opportunity. The gangs in El Salvador, at least for now, have been characterized as "small time crooks", though deadly ones. Unlike the cartels in Colombia and Mexico, at this time, the Salvadoran gangs are only marginally involved in drugs (Martínez et al., 2016).

That said the endemic gang-related violence and extortion is imposing costs not only on the Salvadoran economy but also on the country's social fabric, similar to the effect that a metastasizing cancer will eventually have on a human body. Ironically, the feud between the two principal rival Salvadoran gangs -- Barrio 18 and Mara Salvatrucha (MS-13) -- originated in Southern California: the former came into existence as an offshoot of a Chicago gang called Clanton 14 around the 1950s, while the latter began in the late 1970s. The hatred between the two rival gangs exploded into a bloody war on 
the streets of California in the late 1980s. During the 1980s and 1990s the US government began deporting many of these gang members -- many serving prison sentences in the US -- back to El Salvador and Honduras, where they thrived, exploiting the punishing poverty, the widespread corruption, and the very limited economic opportunities that characterized these Central American countries (Martínez, 2013).

By 2011, El Salvador recorded 70 homicides per 100,000 in population, one of the highest homicide rates in the world. The Funes administration, along with the Catholic church, brokered a secret truce with (and between) the two rival gangs, and the homicide rate retreated to 41.3 per 100,000 in population by March 2013. The government, in collaboration with 11 municipalities, promised "peace zones" and job opportunities in exchange for a halt in the violence, and the imprisoned gang members received improved prison conditions, such as telephone and visiting privileges, and better food. However, the funds for the "jobs program" never materialized, and once the prisoners' "benefits" were rescinded and they were returned to maximum-security prisons the homicide rate rose in 2014, with the new Sánchez Cerén government disowning the 2012 truce to avoid appearing soft on crime, even though the new president served as vice-president at the time of the brokered truce. Despite the new "truce" that was arranged between the two gangs, in 2015 the national homicide rate rose again from its low of 41.3 in 2013 to 108.6 in 2015, according to World Bank data. The gang-related violence has since shifted towards ordinary people instead of intra-gang homicides (The Economist, 2015a; The Economist, 2015b).

Gang membership by late 2015 was estimated at 72,000 people, more than $1 \%$ of the population, however more than $6 \%$ of the Salvadoran population was supported by gang-related "income" if gang members' dependents are included. The gangs recruit children in primary school and extort small business owners such as bus drivers, delivery people, and shopkeepers with a "tax" that increases until it becomes unprofitable to operate. A reported 70\% of businesses are extorted (Martínez et al., 2016). Failure to pay the "tax" results in violence that is often fatal (The Economist, 2015b). Since most gang members concede that they are unlikely to die from natural causes, their long-term prospects seem to be a choice between jail or the cemetery (Martínez et al., 2016). It is clear that with few government/business partnerships to provide economic opportunities, i.e., bakeries, chicken farms, garment factories, etc., to those dependent on the "gang economy", the extreme violence has become institutionalized in El Salvador. Legitimate businesses and corrupt politicians and police have become financially dependent on the gangs to the detriment of civil society and economic progress. Since an estimated $25 \%$ of the population between the ages of 25-29 are neither working nor in school, and there are few programs to employ gangsters or those at risk of becoming gangsters, many businessmen are convinced that jobs are the only solution to getting young people out of the "gang business" and into productive lives (Arce, 2016). In the absence of a program that focuses on improving the "employability" of the gang members that provides them with an alternative "life style" to a life of crime, violence, jail, and premature death by homicide, Salvadoran politicians are likely to continue oscillating between "back-room" temporary truces with the gangs and a mano dura (iron fist) policy. It is worthwhile noting that a recent poll revealed that $40 \%$ of Salvadoran adults approve of torture to combat the gangs and 35\% endorse extra-judicial killings (Ahmed, 2017). Both of these failed strategies do not address the root causes of the gang-related violence that is turning El Salvador into a failed state.

In 2016, according to the United Nations Development Programme, extortion payments to the gangs were estimated at about $\$ 800 \mathrm{~m}$ a year -- approximately 3\% of Salvadoran GDP. However, the total cost of the gang-related violence imposed on the people of El Salvador that includes the amount of money spent by Salvadoran households on extra security and the lost income of people deterred from working because of fear was estimated at approximately 16\% of GDP, almost equal to the amount of money received each year by El Salvador from remittances, mostly from Salvadoran nationals living in the United States, legally and illegally (The Economist, 2016a).

A second major drag that emerged in the wake of the Civil War that retards improving the performance of the Salvadoran economy and raising living standards is the painful subject of reaching an acceptable consensus on adjudicating alleged crimes committed by both sides during the Civil War. The 1993 amnesty shielded from prosecution those guilty of human rights violations on both sides, without 
which it was unlikely that the political settlement that ended the civil war would have been agreed. Weary of 12 years of war, "Salvadorans chose peace over justice", was the way one retired general who represented the army in the peace negotiations described the agreement (The Economist, 2016a).

However, as more information about the wartime human rights excesses was revealed -- such as the atrocity in the village of El Mozote, where soldiers from the Salvadoran army machine-gunned hundreds of unarmed men, women and children -- the amnesty was being questioned (The Economist, 2016a). Since El Salvador's Supreme Court ruled in 2000 that the amnesty did not extend to violations of "fundamental" rights -- though it did not provide guidance on what constituted a "fundamental" right -the Court was considering a constitutional challenge.

In July 2016, the Court ruled that the amnesty -- overwhelmingly favoring the military officers during the war -- was unconstitutional because it denied victims their rights (O'Grady, 2016b). Then President Sánchez Cerén did not support the Supreme Court decision arguing that over-turning the amnesty agreement could fracture the country again. A more self-serving reason for his opposition to the Court's decision was the fact that, as a former guerrilla leader, it is likely that he could be prosecuted in the future (New York Times, 2016). The 1992 UN Truth Commission report contained 22,000 complaints of "serious acts of violence", with $85 \%$ of them registered against the armed forces, paramilitary groups and right-wing death squads, while 5\% of the complaints accused the left-wing FMLN group. Adding to the pressure brought by family members whose relatives were murdered by the opposing sides in the war to rescind the amnesty -- or, at least, to narrow its coverage -- was a $\$ 750 \mathrm{~m}$ proposed aid package from the US to the Northern Triangle countries, one of whose conditions was that governments must prosecute soldiers and police officers suspected of human rights violations (The Economist, 2016a).

To that end and in light of the Court's decision striking down the amnesty law, lawyers for the survivors of the Mozote massacre asked a provincial judge to reopen a trial that began in 1990, well in advance of the 1993 amnesty law. The Mozote trial is ongoing, and among the defendants is a retired general José Guillermo García Merino, who served as defense minister from 1979 to 1983. In 1990 he was granted asylum by the United States, but was sent back to El Salvador in 2015. The trial is expected to extend into 2019 (Malkin, 2018).

The gang-related violence in the Northern Triangle countries in general -- and in El Salvador in particular -- has even spilled over to the United States. Between 2014-16 more than 120,000 children from the Northern Triangle countries arrived -- unaccompanied by their parents -- at the southern US border. In addition, there are an estimated 10,000 Salvadoran gang members in the US involved in selling drugs, buying weapons, and extortion (Blitzer, 2018). The gang-related violence in small towns, such as Huntington on the eastern edge of Long Island in New York State, has led local and federal law enforcement agencies to mount an aggressive campaign to root out alleged adolescent gang members from schools, often resulting in summary deportations (Dreier, 2019).

The recent surge in migrants attempting to enter the United States through the southern border are predominantly from the Northern Triangle countries. While the Trump administration's short-lived policy to separate adult migrants illegally entering the US from their children was designed to discourage migrants from attempting the border crossing, it was also used as a "cattle prod" to force Congress to reform the badly-needed US immigration/asylum policy, which it has been unwilling or unable to do for decades. In the wake of the results from the November 2018 US-mid-term elections, a bi-partisan agreement on immigration/asylum reform that could be signed by President Donald Trump appears ever more elusive.

It would not be an exaggeration to say that the horrific 12-year civil war and the gang-related crime and extreme violence that followed in its aftermath are the principal factors weighing on the performance of the Salvadoran economy and the quality of life of its people. In addition, the geographical region that El Salvador occupies, Central America -- and in particular, the sub-region referred to as the Northern Triangle -- has also played a role in the relatively poor performance of the economy over the last decade. Therefore, this section concludes with a short digression on El Salvador's "neighborhood", Central America. 


\section{Central America: A Brief Survey of El Salvador's Neighborhood}

According to The Economist (2011), the isthmus of Central America is the "most routinely murderous region on earth". The broader region, Latin America, has $8 \%$ of the world's population, but registered $38 \%$ of the world's recorded murders. More than $2 / 3$ of the region's violent deaths were homicides, and the estimated cost of the violence is approximately $3.5 \%$ of annual regional GDP (The Economist, 2018b). One of the symptoms -- some might argue causes -- of living in a "bad neighborhood" is an elevated homicide rate, and El Salvador has the highest rate in the region (and the highest in the world among countries not engaged in war) -- reported in 2016 at 82.8 per 100,000 of population -- more than 10 times the global average, and almost 14 times the US rate, which itself is about five times the rate in the EU (The Economist, 2018b). It is important to note that in El Salvador, $95 \%$ of murders go unsolved, and the country is also among the world's deadliest countries for women, ranking first in Latin America (Lobo-Guerrero, 2017; Forero, 2018).

Violence in the region is not only at a high level, but it is increasing. Central America's Northern Triangle sub-region is arguably the most violent in the world (Washington Office on Latin America, 2018), leading to massive outflows of people from these countries. During the 2011-2016 interval, the US and Mexico have returned more than 500,000 refugees to Central America, including 40,000 children (Kristhof, 2016). According to US Census Bureau estimates more than 4.5 million people of Guatemalan, Honduran, and Salvadoran origin -- approximately 20 percent of the Northern Triangle population -- live in the United States, and 250,000 Central American migrants cross the border from Mexico to the US every year (De Córdoba, 2018).

As one of the three countries in the infamous Northern Triangle along with Honduras and Guatemala, El Salvador, as discussed above, is being undermined and overwhelmed by egregious levels of violence, insecurity, and corruption that have their origin in the country's civil war and its aftermath -- the years of national reconciliation and economic renewal, which spanned the decade of the 1990s. According to researchers, high murder rates have lots of causes: "fragile governments, guns and fighters left over from wars, families broken up and forced into the city by rural violence and poverty, drugs and organized crime that police cannot or will not confront, and large numbers of unemployed young men" (The Economist, 2018b). Most, if not all, of these ingredients appear to be in place in El Salvador, as discussed above.

With respect to corruption at the highest levels of government, the attorneys-general in the Northern Triangle countries have done an admirable job of bringing charges of corruption against officials in state agencies, presidents, vice-presidents and former presidents of these countries, only to meet considerable resistance from entrenched politicians and administrators whose interests are being threatened by the "war on corruption" waged by the attorneys-general (The Economist, 2017; The Economist, 2018c).

Over the last few decades, Central American countries -- and in particular the countries of the Northern Triangle -- have been in the frontline of the drugs trade and organized crime since the region is wedged in between the world's largest cocaine-producing countries (Colombia, Peru, and Bolivia), Mexican cocaine traffickers, and the world's largest consumer market for cocaine, the United States. Though Salvadorans pay an estimated $\$ 800 \mathrm{~m}$ a year, about 3\% of GDP, to the gangs for extortion payments, the gangs don't yet have the wealth or the political power of the Mexican drug cartels, but the fear is if the gangs are not contained, they will evolve into full-scale drug-trafficking networks to rival those in Mexico, Honduras and Guatemala even though today they are involved in drugs only marginally (Arce, 2016; The Economist, 2016b; Martínez et al., 2016).

Natural disasters are also part of the landscape. Four of the seven countries in the region have been classified as among the most vulnerable in the world to destructive weather or other acts of nature including hurricanes, floods, landslides, earthquakes, and volcanic eruptions (The Economist, 2011). Besides sharing these nature-related attributes, Central American countries also possess some economic commonalities as well: they are all relatively small -- though not "micro" -- emerging economies; most are susceptible to some commodity dependence (such as importing oil and exporting agricultural commodities, both of which experience considerable price volatility); most are net recipients of international remittances; the Central American economies all exhibit high inequality in the distribution 
of income and wealth; and most have large informal sectors which contribute to the poor quality of economic data and contribute to weak economic institutions (IMF, 2016b; p. 29).

The data presented in Table 1, below, provide a snapshot of El Salvador's relative position with its regional neighbors for some generally accepted indices of "quality of life" and economic wellbeing.

TABLE 1

\section{CENTRAL AMERICA: A SNAPSHOT OF THE REGION ${ }^{\mathrm{a}}$}

\begin{tabular}{|c|c|c|c|c|c|c|}
\hline Country & $\begin{array}{c}\text { GDP } \\
\text { per Capita }\end{array}$ & Population & \begin{tabular}{|c|} 
Population \\
Below Poverty \\
Line
\end{tabular} & \begin{tabular}{|c|} 
Informal \\
employment
\end{tabular} & $\begin{array}{c}\text { Physician } \\
\text { Density Rate }\end{array}$ & $\begin{array}{l}\text { Homicide } \\
\text { Rates }\end{array}$ \\
\hline & $\begin{array}{c}\text { (2017 US\$, } \\
\text { ppp) }\end{array}$ & $\begin{array}{l}\text { (Millions, } \\
\text { 2017) }\end{array}$ & $\begin{array}{l}\text { (\% of Pop., } \\
\text { 2016) }\end{array}$ & $\begin{array}{c}\text { (\% of non- } \\
\text { agri. } \\
\text { employ.) }\end{array}$ & (per 1000 Pop.) & $\begin{array}{c}\text { (per 100,000 Pop., } \\
2016)\end{array}$ \\
\hline Belize & 8,300 & 0.36 & 41.0 & N.A. & 0.83 & 37.6 \\
\hline Costa Rica & 17,200 & 4.93 & 20.5 & 35.5 & 1.15 & 11.9 \\
\hline El Salvador & 8,900 & 6.17 & 38.2 & 63.2 & 1.60 & 82.8 \\
\hline Guatemala & 8,200 & 15.46 & 59.3 & 73.5 & 0.90 & 27.3 \\
\hline Honduras & 5,500 & 9.04 & 60.9 & 73.8 & 0.39 & 56.5 \\
\hline Nicaragua & 5,800 & 6.03 & 24.9 & 75.0 & 0.91 & 7.4 \\
\hline Panama & 24,300 & 3.75 & 22.1 & 41.0 & 1.59 & 9.7 \\
\hline
\end{tabular}

a. Latest available data

Source: CIA, 2018; http://data.worldbank.org; https://dataunodc.un.org/crime/intentional-homicide-victims

\section{PART 2. THE METHODOLOGICAL FRAMEWORK}

Before discussing the areas in which reform will be needed to improve the long-term performance of the Salvadoran economy to the end of raising living standards, it is worthwhile reviewing some of the alternative "paths to prosperity" that have been proposed by the leading development experts -individuals and institutions -- since the middle of the 20th century.

The ideas of Raúl Prebisch (1959) and Hans Singer (1964) provided the intellectual firepower for the development blueprint anchored in "import substitution" because their thesis was based on the declining terms of trade for primary products and the dynamic benefits to the economy of a vibrant manufacturing sector. These concepts became operational policy in most of Latin America in the 1960s-70s, ensuring a large and growing role of the state in the economy through supportive taxes and subsidies if not direct ownership of productive capacity.

The role of state involvement in the economy for development purposes that is a corollary of the Prebisch-Singer thesis was actually the foundation of the work proposed earlier by Paul RosensteinRodan (1943) and P.C. Mahalanobis (1955), which stressed increasing returns to scale and kick-starting growth through large-scale investments, and accelerating economic development by government encouragement of heavy industry, respectively.

These "inward" winds of economic development shifted in favor of more "outward" and "marketoriented" strategies that were advanced during the 1970s by Balassa (1971), Bhagwati (1978), Krueger (1978), and Little, Scitovsky, and Scott (1970). The "market-based" approach to improving the performance of the economy and to enhancing living standards reached its zenith with the views of a group of Latin American economists and policymakers, the World Bank (1991), and various academic and "think tank" development experts such as John Williamson (1994) with the so called "Washington Consensus" of the 1990s. For example, in its 1991 World Development Report, the World Bank articulated four broad requirements that characterize a national economy as "battle ready" to meet the challenges of the fiercely competitive world economy at the end of the 20th century. They included: 
A stable macro-economy characterized by both fiscal and external balance and low and stable inflation;

The adoption of a competitive micro-economy that includes a substantial reduction in state ownership and management of productive assets and the elimination of price distorting subsidies and taxes;

Strong global linkages that include adherence to GATT (now the WTO), low and uniform tariff rates, absence of non-tariff barriers, a uniform and market-determined exchange rate, a liberalization of the rules governing capital flows and foreign direct investment and;

An active government policy that promotes social and economic investment, especially in the areas of education, infrastructure, and health.

In its 1997 World Development Report (World Bank, 1997), the Bank expanded the reach of the fourth requirement to include the promotion and enforcement of property rights, reducing the level of corruption in the country, and ensuring a reliable legal system -- some of the so-called "second tier" reforms.

The "Washington Consensus" (WC), which was originally compiled in 1990 and published by John Williamson (1994), enumerated a list of desirable conditions that, if adopted and adhered to, would, over time, put reforming countries on the path to success in the global economy.

TABLE 2 MODIFIED "WASHINGTON CONSENSUS"

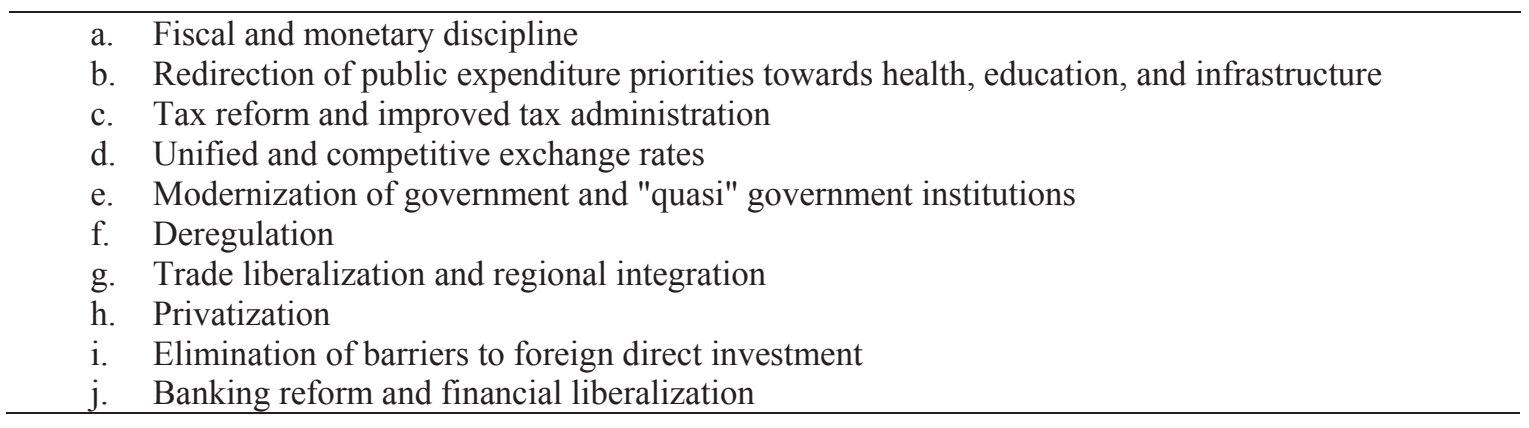

Since the late 1990s, because of its alleged failure to address the issue of poverty reduction directly, the Washington Consensus was subjected to heated intellectual debate within academia and the major international organizations such as the World Bank (Beattie, 2000). Nevertheless, this framework continued to assume a central role in the debate on development strategies for low- and middle-income developing countries during the first decade of the $21^{\text {st }}$ century. Readers interested in this debate are referred to Rodrik (2010) for a review of this subject. (Please see Table 2, above, for a list of its main points).

In light of the experience of the late 1990s (increasing poverty rates and stalled economic growth due to an adverse external environment), proponents of the Washington Consensus amended the original framework to ensure that fiscal policy is counter-cyclical to support economic growth in an economic downturn, and to focus on reducing income inequality by ensuring that the poor have access to assets, i.e., education, land titling, micro-credit and land reform, that will enable them to work themselves out of poverty (Williamson, 2003).

With respect to Venezuela, with accelerating hyper-inflation that reached almost $1,000,000 \%$ in 2018 , GDP declined by more than $40 \%$ from 2013 to 2018 , and the poverty rate increased from $48 \%$ to $87 \%$ from 2014 to 2017. Despite winning a sham election in May 2018, the leftist-populist Maduro regime appears to be nearing its endgame (The Economist, 2018a; Kurmanaev, 2018; Long, 2018). In contrast, despite promising reforms in the energy and education sectors implemented in the initial years of the Peña Nieto administration in Mexico, increasing levels of corruption that reached even the President's own 
household and the increasing levels of drugs-linked violent crime and insecurity resulted in the election of Andrés Manuel López Obrador (AMLO), a leftist-nationalist, in the July 2018 presidential election.

In a review article of economic development blueprints, Dani Rodrik (2010) assessed the experience of China, which over the last three decades arguably has had the most successful growth and poverty reduction program in recorded history, and notes that there does not appear to be any single orthodox Western economic plan that was adhered to by Chinese economists and policymakers.

Rodrik also observed that even in (now relatively prosperous) Chile -- admitted to the Paris-based club of "rich" countries, the Organization of Economic Cooperation and Development (OECD) in 2010 -during the 1970s-80s a strict universally scripted development plan was abandoned and a more heterodox (and indigenously articulated) strategy was adopted even during the tense Pinochet era.

It now appears, according to Rodrik, that a more fruitful approach to prescribing a successful path to economic growth and development is one that is based on "diagnostics', as proposed by Hausmann, Rodrik, and Velasco (2008), and Hausmann, Klinger, and Wagner (2008). In place of a "boiler plate" set of rules and a rigid, unyielding approach to growth these development economists propose to identify a country's binding constraints and then prioritize the policy reforms given the political and social realities of the country involved. These authors argue that the earlier, carefully scripted paths to growth and development have not lived up to their expectations:

"The currently prevailing view, as reflected in the World Bank's (2005) report on the lessons from the 1990s or by the blue-ribbon Commission on Growth and Development (2008), accepts the importance of outward orientation but places much less emphasis on trade liberalization and is much more willing to condone a measure of industrial promotion in order to achieve and sustain high growth" (Rodrik, 2010; p. 40).

Rodrik praised China's so-far successful development approach of grafting a market system on top of a heavily regulated state sector (that was the orthodoxy of an abandoned Communist economic system) with China's development plan evolving over time as their binding constraints change: first in agriculture; then in industry; then in foreign trade; and eventually in finance, the environment, and pension reform.

It is important to note that despite its impressive poverty reduction cum economic growth program now in its fourth decade, China enjoys enormous leverage in the world because of its population of $1.4 \mathrm{bn}$ people -- almost $20 \%$ of the world's population -- that is increasingly willing and able to become " $21^{\text {st }}$ century consumers". China's voracious appetite for fuel and non-fuel minerals (Sohn, 2008a; Sohn, 2008b), "first world" foods and diets, electricity and other infrastructure goods, along with its still large though increasingly more expensive labor force, provides it with enormous "monopoly-like" and "monopsony-like" power on world resource, factor, and product markets. The market access that it provides for the goods and services of global companies confers on China tremendous leverage regarding the terms it dictates for foreign (inward and outward) investment, the aid and foreign investment programs it operates, and its managed foreign exchange and capital account regimes. Needless to say, the "China model" is being challenged by the Trump administrations's increasingly assertive policies towards China that are not limited to the "trade war" that erupted at the beginning of 2018.

On the other hand, problems abound: simmering problems continue with its slowly reforming banking system, the chronic overcapacity in its resource and manufacturing sectors that, in part, triggered tariffs on US imports of steel and aluminum in 2018, the widespread corruption in the country, its increasingly vexing problem to balance its global environmental responsibilities with its commitment to economic growth and improved living standards, and its continuing high debt level that is projected to stabilize at $260 \%$ of GDP in 2018, in addition to the growing divide between China's rural and urban areas, which includes the intractable issue of internal migration from the country-side (The Economist, 2016c; Kynge, 2016; Financial Times, 2016; Magnier and Cui, 2017). To be sure, particularly in the wake of the 2008-9 global financial crisis and the need for substantial global rebalancing, China's trade, savings, investment, capital account, and exchange rate policies are exacerbating the adjustments that are needed and increasing the political and diplomatic tensions in the world. The jury is still out whether 
China's one-party political system can be maintained with continuing globalization and technological change. It will be of interest to follow China's increasingly assertive -- and some might say aggressive -challenge to the perceived supremacy of the liberal Western democratic system over the next decade especially in light of the policy changes introduced by the Trump administration in its first two years in office in foreign affairs, energy and climate change, and immigration and trade (Runciman, 2018).

Nevertheless, over the last few years, after a prolonged internal debate in juxtaposing the harsh economic and financial consequences of the 1997-98 Asian crisis with the relative calm in China in the aftermath of the 2008-09 global financial crisis, the thinking of the International Monetary Fund has evolved on the need for, and desirability of, capital account liberalization as the complement of already liberalized current accounts for developing countries. This new 'institutional view', discussed below, recognizes that liberalizing "developing countries capital accounts before they have reached a certain level of financial and institutional development is highly risky" (Plender, 2012).

Daron Acemoglu and James Robinson (2012) argued in favor of the critical role played by economic institutions in explaining the enormous differences in living standards across the world. They contend that these institutions determine the economic incentives and the resulting allocation of resources, investment, and innovations needed for growth. Ultimately, it is politics that shape these institutions and their evolution. It will be interesting to track, over the next few decades, the evolution of China's political system -- especially in the wake of slower growth since 2010 and a rebalancing of its economy away from exports and investment towards consumer spending -- if the changes that are introduced support the "right economic institutions" argument as proposed by Acemoglu and Robinson. It is important to note a major new study by Joel Mokyr (2017), arguably the leading economic historian of our time, on the role institutions -- more broadly described as "culture" (beliefs, values, and preferences) -- play in nurturing economic growth and development that led to the sustained rise in living standards in western Europe and its offshoots in the New World since the Industrial Revolution.

The winds of globalization have shifted in the second decade of the 21 st century as the growth in world trade slows due, in part, to economic, social, and political stresses in the developed countries, the result of anemic growth in GDP growth since the Great Recession, increasing income inequality, lower employment participation rates even as official unemployment rates are normalized, and technological change continues in the manufacturing and service sectors. Even though some proposals on liberalizing global and regional trade and investment have been withdrawn (at least temporarily), in 2017 both Canada and Japan concluded important bilateral trade agreements with the EU (Rao and Ewing, 2017), and an expanded FTA between the EU and Mexico was approved in April 2018. The June 2016 vote in the Brexit referendum in the UK and the election in November 2016 of Donald Trump in the US serve as examples of the political backlash resulting from the above social and economic stresses. Some recent examples of the populist pressures driving current US trade policy include the withdrawal of the US from the Trans-Pacific Partnership (TPP), a regional trade initiative among the remaining eleven Asia-Pacific economies that has now been completed; the suspension of negotiations to complete the Transatlantic Trade and Investment Partnership (TTIP) with the EU; and the recently completed revision of the North America Free Trade Agreement with Canada and Mexico, which has not yet been ratified. In addition, as mentioned above, import tariffs on steel and aluminum announced by the Trump administration in early 2018 and retaliatory tariffs announced by the EU, China, and other US trading partners risks igniting a major global trade war, reminiscent of the Smoot-Hawley era of the 1930s. The increasing trade tensions are impacting global growth, especially in China, whose contribution to global economic growth has been indispensable for the last two decades (Hannon and Zumbrun, 2018).

Recently Harvard economist Dani Rodrik (2018) criticized the half-century of bilateral, regional, and global trade agreements for over-emphasizing the growth aspects of the deals and under-emphasizing the negative effects of free trade, that is, the "domestic social disintegration", which would include, inter alia, increased income inequality in developed countries, lower labor participation rates, etc., because of the effects of trade on incomes and employment, and argues for stronger "safety nets", such as assuring more aid and training for workers who lost their jobs because of international competition (Madrick, 2018). 
The next section which takes the measure of the Salvadoran economy -- along with the challenges it faces and the opportunities that can be seized -- relies heavily on the "ingredients" prescribed in the market-based and outward-looking approach to economic growth and development noted in the abovementioned World Bank reports, while at the same time being mindful of the contributions made by those advocating a more tailored approach to development that identifies binding national constraints and priorities in the quest for economic modernization over the next decade, in addition to the issues raised by Rodrik on the need for enhanced "safety nets" to mitigate the negative effects of trade (and technology) on incomes and employment and the important role of institutions cited by Acemoglu and Robinson and culture by Mokyr, that was discussed above.

\section{PART 3. THE STATE OF THE SALVADORAN ECONOMY: STRENGTHS AND WEAKNESSES}

\section{Macroeconomic Stability}

With a view towards improving the performance of the Salvadoran economy during the next decade it is useful to take the measure of the current state of the economy following the World Bank's "recipe" described in Part 2, above. Before examining the current state of the economy, this section begins with a short description of some of the improvements in material well-being that accompanied the post-civil war period (1992-2007) as a result of the government's comprehensive program of economic reform (Hidalgo, 2009).

Per capita GDP -- valued in 2005 US dollars -- declined from \$5,500 in 1978 (on the eve of the civil war) to $\$ 3,700$ in 1982 , where it remained until the conclusion of the war in 1992. In the post-civil war period of economic reconstruction and renewal (1992-2007), official GDP per capita increased by 1.9\% p.a., and unofficially -- once some alleged measurement errors were accounted for in the fast growing service sector -- per capita GDP rose by $5.2 \%$ p.a. While it may not be possible to reconcile these "alternative facts", that is, the large difference in the two per capita GDP growth rates -- there is no dispute regarding the improvements in the amenities enjoyed by the Salvadoran public that mirrored the increasing per capita GDP levels. Between 1991-2002 net enrollment in primary education increased by $10 \%$, infant mortality declined by $40 \%$, the percentage of the population without access to safe water declined by $50 \%$, the number of Salvadorans living in extreme poverty fell by half (to $10.8 \%$ of the population), the number of households with electricity, refrigeration, and televisions increased by $20 \%$, and the number of households using firewood for cooking declined by $24 \%$ (Hidalgo, 2009).

However, since 1996, with the exception of 1997, 2006 and 2011, annual GDP growth has been below 3\% p.a. -- and since 2000 annual GDP growth has averaged only about 2\% p.a. -- regardless of which of the two principal parties were in power, the center-right ARENA or the leftist FMLN party. As a result, this "low-orbit growth" that El Salvador has settled into appears to be more related to the intractable long-term structural and institutional problems discussed above -- the endemic corruption, violence and crime that weigh heavily on private business investment from both foreign and domestic sources, the distortions in the labor market that include the large scale emigration of young workers over the last 20 years, and the high percentage of Salvadorans working in informal employment (Table 1, above) rather than the politically-driven economic policies implemented by the successive Salvadoran administrations.

The first of the four broad requirements needed for a well performing national economy is macroeconomic stability, generally characterized by both fiscal and external balance, low and stable inflation, and high levels of employment. It would be of interest to examine these macro-variables over the last six years, that is, how the Salvadoran economy performed over the 2012-17 period. The data in Table 3, below, indicate that annual GDP growth in El Salvador in the 2012-17 interval -- averaging approximately $2 \%$ p.a. (the so-called "low-orbit growth") -- has consistently been well below annual GDP growth in the immediate sub-region of Central America. Also, as described in Table 3, it is important to note that Central America has recorded significantly higher GDP growth over this interval than the larger Latin America and Caribbean region, most likely because the sub-region's economies are more closely 
aligned with the US than with South America. In addition, as mentioned above, two of the largest South American countries -- Brazil and Venezuela -- recorded negative GDP growth the last few years, explaining the overall negative regional growth rate in 2015 and 2016.

Since the onset of the Great Recession in 2007, World Bank data indicate that the performance of the Salvadoran economy closely shadows that of the US economy. The US is El Salvador's most important trading partner, absorbing about 50\% of the latter's exports; is the source of one-third of all inward Salvadoran foreign direct investment (FDI); and of 90\% of its international remittances, which reached $17 \%$ of El Salvador's GDP in 2017. The International Monetary Fund projects that annual GDP growth in El Salvador will remain within the "low-orbit growth" of approximately $2 \%$ p.a. at least until 2023, and raising potential GDP growth above $2.5 \%$ p.a. awaits structural and/or institutional reforms that require first unlocking the political deadlock that has plagued the country for years (IMF, 2018).

El Salvador's historically low investment to GDP ratio (Table 3, below) is both a cause and a symptom of its low GDP growth rate. For the 2013-17 interval its average ratio of investment to GDP was the lowest in Central America, with the exception of Guatemala (IMF, 2018, p. 24). Also, El Salvador's highest ratio of investment to GDP -- about 18\%, that was recorded during the 2000-08 interval -- was below the lowest ratios registered for the rest of the Central American countries (plus the Dominican Republic) since 1980, which, in turn, were well below the average ratio of Brazil, Chile, Colombia, Mexico, and Peru since 1990 (IMF, 2018, p. 24). While super-charged economic growth rates such as experienced in recent years in China require extremely elevated investment to GDP ratios in the range of $30-45 \%$, moderate long-term economic growth rates are usually accompanied by investment to GDP ratios between 20-24\%. The ratios in Table 3 for El Salvador for the 2012-2017 interval are well below that threshold, and, consequently, once again, El Salvador appears to be "stuck in low-orbit growth".

On the other hand, "normal" investment to GDP ratios in El Salvador -- that are an indispensable ingredient for higher growth prospects -- are being undermined by the following array of impediments: political polarization; high crime; rising unit labor costs (in part caused by the adoption of the "dollarization" policy implemented in 2001); high energy costs; barriers to entry; high exposure to natural disasters; fiscal and regulatory uncertainty; and limited human capital, the result of the emigration of many potentially productive young Salvadorans fleeing violence and the lack of economic opportunities (IMF, 2016a).

While El Salvador's fiscal deficits have been declining since 2014, the country's debt-to-GDP ratio continues to increase, reaching $71 \%$ at the end of 2017 , much higher than the normal range of $20-50 \%$ for the Central America region. One of the consequences of a rising debt ratio is a bond rating that is below investment grade that raises the cost of financing state debt and the cost of domestically issued debt instruments. Needless to say, with slow GDP growth even modest annual fiscal deficits of $2.0-2.5 \%$ will continue to raise the debt ratio now approaching dangerous levels.

The IMF advised El Salvador to adopt a Fiscal Responsibility Law (FRL) whose objective is to institutionalize fiscal discipline, transparency and stability. This mechanism sets expenditure rules to reduce annual budget deficits, and, over time, stabilizes -- and later reduces -- the country's debt ratio. In Central America, both Panama and Honduras have adopted the discipline imposed by these FRLs. A "custom made" FRL for El Salvador would have to incorporate some of the country's unique challenges such as "full dollarization" which implies that El Salvador does not have an independent monetary policy or a lender-of-last-resort. (More about this below). Also, the unsustainable fiscal environment is heavily influenced by a pension system that is seriously flawed and in need of reform. (More about this, too, below).

Since adopting fiscal rules would require changes in both the level and direction of spending and the level and sources of taxes, given the high political polarization of Salvadoran society -- a vestige of the civil war in the 1980s that is reflected in the ideological differences between the FMLN and ARENA, the two main political parties in the Salvadoran parliament -- reaching agreement on an acceptable FRL is likely to be challenging. The FMLN favors increasing state revenue by higher income taxes and levying a tax on property income, while ARENA supports restraining public spending. According to a 2015 World Bank study, "the Salvadoran parliament is the most polarized in Latin America" (IMF, 2016a, p. 30). 
In 2017, in addition to the pension reform to be discussed below, El Salvador successfully enacted a "lite FRL" that introduces gradual fiscal adjustment and, according to the IMF, "represents a step in the right direction, but the law and its supporting elements would benefit from further updates and refinements" (IMF, 2018, p.13). The Fiscal Responsibility Law stipulates a floor on taxes of 17\% of GDP beginning in 2020, and a ceiling on current government expenditures of $18.5 \%$ of GDP, as well as a cap on spending on public wages, goods, and services (IMF, 2018; p.13). More specifically, though progress has been made in reducing the fiscal deficit and stabilizing debt at $65 \%$ of GDP, further efforts are needed to put debt on a declining trajectory, to $60 \%$ by 2024 and to $50 \%$ by 2030 . The new pension reform -which reduces the annual fiscal deficit by around $0.8 \%$ of GDP over the next few years -- does not go far enough to provide a comprehensive fix to the system. (Please see below).

Turning to inflation, despite the large increase in the minimum wage $(20 \%$ for urban workers and almost $100 \%$ for some agricultural workers in late 2016), because of successful harvests and lower global oil prices since 2014 until the end of 2016, annual inflation rates over the 2012-17 interval have been subdued, mirroring the inflation rates in the US to which the Salvadoran economy is anchored with its dollarization policy. (Please see Table 3). Inflation over the last six years in the Latin America and Caribbean region, even after excluding Venezuela which is currently in a state of hyperinflation, averaged about $6 \%$ p.a. over the interval.

Regarding the rate of unemployment, the national estimates presented in Table 3 report that El Salvador's unemployment rate was generally below the broader Latin America and Caribbean region metric. This is most likely the result of the continuing economic problems in the largest Latin American economies, Argentina, Brazil and Venezuela. It is also important to note that El Salvador's urbanization rate of about $69 \%$ is below the regional average of $80 \%$, recalling that Latin America is the most urbanized region in the world (Urbanization in Latin America, 2018). That said, with only a little more than one-third of the non-agricultural labor force employed in the formal economy even though, according to the United Nations (2017) this metric is increasing slowly over time -- Central American countries generally have highly informal labor markets (please see Table 1) -- it would be a leap in logic to presume that the official unemployment numbers accurately reflect current labor market conditions. To be sure, both the unemployment rate and the estimated labor force in El Salvador and the other Northern Triangle countries are heavily influenced by out-migration -- mostly to the United States -- of so many young people over the last 30 years.

Turning to El Salvador's current account deficit as a percent of GDP, the deficit has receded from an average of more than $6 \%$ in the first 3 years of the 2012-17 interval to an average of $3 \%$ in the last 3 years of the interval, of which some of the improvement in the current account deficit can be attributed to lower global oil prices. It is important to note that El Salvador's current account balance is heavily influenced by global oil prices, so if the fall in the price of oil in the fourth quarter of 2018 can be maintained, El Salvador's current account balance could be expected to improve in the short-term. However, on the trade account, El Salvador continues to import almost twice as much as it exports in value terms, generating merchandise trade deficits of about $20 \%$ of GDP (IMF, 2018, p. 30).

Foreign remittances from Salvadoran nationals mostly resident -- legally or otherwise -- in the US generate financial flows equal to $18-20 \%$ of GDP, or dollar values approximately equal to El Salvador's annual export revenues. Needless to say, the Trump administration's crackdown on illegal immigrants, changes in the border policy for legal immigrants and asylum seekers, and the decision by the US administration in January 2018 to end the temporary protection status (TPS) for Salvadoran immigrants poses risks to remittances inflows. (In October 2018, the U.S. District Court for the Northern District of California blocked the US Department of Homeland Security from implementing the decision to terminate Temporary Protected Status (TPS) for nationals of El Salvador and three other countries, pending further review of the case). Needless to say, any major reduction in these remittances will have serious consequences for Salvadoran growth prospects.

Journal of Applied Business and Economics Vol. 21(7) 2019155 
TABLE 3

MACROECONOMIC DATA: EL SALVADOR AND LATIN AMERICA, 2012-2017

\begin{tabular}{|c|c|c|c|c|c|c|}
\hline Macroeconomic Variable & 2012 & 2013 & 2014 & 2015 & 2016 & 2017 \\
\hline \multicolumn{7}{|l|}{ Gross Domestic Product (annual \% change): } \\
\hline \begin{tabular}{|l|l|} 
El Salvador \\
\end{tabular} & 1.9 & 1.8 & 1.4 & 2.3 & 2.4 & 2.4 \\
\hline $\begin{array}{l}\text { Central America + Cuba, Dominican Republic } \\
\text { and Haiti }\end{array}$ & 4.0 & 3.7 & 4.0 & 4.7 & 3.5 & 3.3 \\
\hline Latin America and Caribbean & 2.8 & 2.8 & 0.9 & -0.2 & -0.7 & 1.3 \\
\hline \multicolumn{7}{|l|}{ Gross Fixed Capital Formation ( $\%$ of GDP): } \\
\hline El Salvador & 14.3 & 15.4 & 14.2 & 15.0 & 14.6 & 14.5 \\
\hline Latin America and Caribbean & 21.3 & 21.3 & 20.7 & 19.5 & 18.7 & 17.9 \\
\hline \multicolumn{7}{|l|}{ Central Government (Overall) Balance (\% of GDP): } \\
\hline El Salvador (IMF, 2018; p.28) & -4.3 & -4.5 & -3.9 & -3.8 & -3.4 & -2.5 \\
\hline Latin America and Caribbean & -2.5 & -2.1 & -2.8 & -2.8 & -2.7 & -2.8 \\
\hline \multicolumn{7}{|l|}{ Consumer Prices (annual \% change): } \\
\hline \begin{tabular}{|l|l|} 
& El Salvador (IMF, 2018; p. 25) \\
\end{tabular} & 1.2 & 0.8 & 1.1 & -0.7 & 0.6 & 1.0 \\
\hline Latin America and Caribbean $^{\mathrm{a}}$ & 4.9 & 5.0 & 6.3 & 7.9 & 7.3 & 5.3 \\
\hline \multicolumn{7}{|l|}{ Unemployment Rate (annual \%): National Estimate } \\
\hline El Salvador (Urban) & 6.2 & 5.6 & 6.7 & 6.5 & 6.9 & NA \\
\hline Latin America and Caribbean & 7.3 & 7.1 & 6.9 & 7.3 & 8.9 & 9.4 \\
\hline \multicolumn{7}{|l|}{ Central Government Expenditure (\% of GDP): } \\
\hline El Salvador & NA & NA & 17.4 & 17.0 & 17.1 & 17.8 \\
\hline Latin America and Caribbean & 26.4 & 25.0 & 24.7 & 24.9 & 24.8 & 24.9 \\
\hline \multicolumn{7}{|l|}{ Current Account Balance ( $\%$ of GDP): } \\
\hline El Salvador (IMF, 2018; p. 30) & -6.0 & -7.2 & -5.4 & -4.0 & -2.2 & -2.5 \\
\hline Latin America and Caribbean & -2.3 & -2.7 & -3.1 & -3.4 & -2.2 & NA \\
\hline
\end{tabular}

${ }^{a}$ without Venezuela

Source: United Nations (2013-17); IMF (2018);

http://data.worldbank.org/indicator/;

http://estadisticas.cepal.org/cepalstat/Perfil_Regional_Economico.html?idioma=english

\section{The Adoption of a Competitive Microeconomic Environment}

According to the World Bank (1991), improving the microeconomic foundation of the national economy includes, among other things, a substantial reduction in state ownership and management of productive assets; deregulation to the end of reducing burdensome costs to business and promoting competition; the reduction and/or elimination of price distorting subsidies and taxes; increasing the efficiency of public sector spending and modernizing government institutions; and introducing banking reform and, when prudent, financial liberalization. These institutional changes, if correctly implemented, will reduce the cost of providing public sector services, reward consumers with lower prices, increase the level of economic activity and the percentage of the population that is engaged in the formal economy, and encourage economic, financial and social inclusion.

In 1992, in the wake of the civil war, the Salvadoran economy was in tatters as described above. Under the guidance of four successive governments from the center-right ARENA party, the Salvadoran economy was transformed with the privatization of state-owned enterprises (SOES), especially banks, which were nationalized in 1980; widespread deregulation was adopted -- especially in the telecommunications, energy, and hydrocarbons sectors -- to promote competition and enhance efficiency that lowered prices and increased the quality of these essentials services to consumers; the pension system 
modeled on the 1981 Chilean experience was privatized; and El Salvador adopted full-dollarization of the economy (to be discussed in the next section). In addition, major initiatives were undertaken to liberalize trade by reducing and/or eliminating trade barriers, in part through entering into regional and bilateral trade agreements with other countries. (More about this below). By the late 1990s, as a result of the reforms implemented by the successive ARENA governments, El Salvador was considered the second most "economically free" country in Latin America, after Chile (O'Grady, 2016a).

However, since the leftist FMLN party assumed power in 2009 many of the reforms introduced in the 1990 s were diluted or reversed. For example, because of El Salvador's "low-orbit growth" of around 2\% p.a., government tax revenue is not increasing sufficiently to continue the transition to the privatized pension system as it was originally formulated, requiring additional borrowing by the government to plug the perennial budget deficits that have increased the country's debt ratio to excessive levels. The structural deficits in the pension system, according to the IMF, are equal to about $2 \%$ of annual GDP (IMF, 2016a). Because of the high degree of informality in the Salvadoran labor market (only 24\% of workers in the labor force pay pension contributions), and, at this time, only $11 \%$ of those over 65 receive pension benefits -- the lowest rate of coverage in Latin America (IMF, 2016b, p. 56). Readers interested in a more detailed discussion of the causes for the privatized system's financial un-sustainability -- and some of the suggested remedies to reduce its medium-term fiscal burden and to ensure its long-term viability -- are referred to the 2018 IMF Article IV Consultation Staff Report on El Salvador (IMF, 2018).

For domestic political reasons, despite the urging of the IMF, El Salvador has maintained energy and transport subsidies, though the cost of these subsidies has declined from $1.8 \%$ of GDP in $2011,0.9 \%$ of GDP in 2015, to $0.6 \%$ of GDP in 2017 (IMF, 2018, p. 26). Always in search of new sources of revenue, the government instituted a banking transaction tax in 2014 and, in 2015, introduced new taxes on telecoms services and on large enterprises profits. The IMF has argued that both the bank transactions and telecoms services taxes yield little additional revenue, and they impede, rather than promote, "financial inclusion". It is important to note that only $34 \%$ of Salvadorans hold bank accounts, compared with the regional average of $47 \%$ (IMF, 2016b).

On the other hand, the IMF has recommended a reduction in the corporate income tax, currently $35 \%$, and the personal income tax rate of $30 \%$, contending that because of the high rate of informality and the low ratio of investment to GDP, lower rates on both would be favorable, along with closing loopholes and removing exemptions that would broaden the tax base. Despite the well-known regressivity of the valueadded tax (VAT) which was introduced in 1992, in order to enhance government tax revenue the IMF argued that the VAT rate, currently $10 \%$, should be raised to the regional average of $15 \%$, along with the introduction of a wealth tax in place of higher income taxes, taxing (the highly inequitable) pensions, and increasing higher marginal tax rates at the top of the income scale (IMF, 2016a).

To improve the competitiveness of the Salvadoran economy which is fully dollarized, the IMF cited the need of Salvadoran authorities to enhance the flexibility of wages and prices in the economy, and in particular, to focus on restraining increases in the minimum wage in the absence of demonstrated productivity increases. While this would likely impact the poor adversely, raising wages without compensating productivity changes would lead to higher labor costs, lower profit margins and/or a loss in competitiveness for domestic producers. The government has more "efficient" means to provide income and amenities to the poor than to distort wage rates.

In addition, to improve the efficiency of the economy and strengthen competitive forces the IMF recommended easing the barriers to entry in the transport and electricity sectors and eliminating price fixing in key sectors such as air transport, pharmaceuticals, iron, and agricultural markets (sugar, rice and fertilizers) (IMF, 2016a; p. 15). The latter two will require a stronger Competition Superintendent to provide a clear regulatory path and strong enforcement methods.

Currently the electricity sector is open to private participation, both domestic and foreign. A concession is required only in order to generate electricity from hydraulic or geothermal sources. Most electricity generation and all distribution is in the hands of private companies, while transmission is in the hands of a state-owned operator (World Trade Organization, 2016). 
In the telecommunications sector, a concession is needed in order to provide fixed and mobile telephone services and to exploit the regulated-use spectrum. There are no restrictions on the origin of the capital of telecommunications operators except in the case of free-to-air or subscription radio and television broadcasting services, which are reserved for Salvadoran nationals. El Salvador reformed the sector's legal framework by adopting regulations implementing the Law on Telecommunications, which govern, among other things, the granting of concessions and interconnection between operators. Another amendment allows the regulator to conduct an annual review of the maximum tariffs for fixed and mobile telephone services and charges for interconnection (World Trade Organization, 2016).

For its part, the Heritage Foundation (2018), the Washington-based conservative think tank which publishes a ranking of countries based on an index of "economic freedom" that incorporates metrics on the rule of law, size of government, regulatory efficiency, and open markets, ranked El Salvador 4th out of 7 Central American countries, and 13th of 25 countries in the Latin America and Caribbean region. In addition, they note that the country has been on a downward trend, i.e., "less free economically", since the leftist FMLN assumed power in 2009.

The World Bank's Doing Business (2018) project provides objective measures of the ease of doing business that focuses on business regulations and their enforcement across 190 economies and looks at domestic small- and medium-size companies and measures the regulations applying to them through their life cycle. In its 2018 report, El Salvador, ranked 73rd, improving its ranking by 22 notches from the Bank's previous report, and within Central America, only Costa Rica ranked higher. The World Bank's ranking incorporates how countries perform with respect to a number of categories that are important to nurturing and sustaining local businesses that include: starting a business, arranging for electricity, protecting minority investors, enforcing contracts, resolving bankruptcy, ease in paying taxes and obtaining construction permits. The Bank cited El Salvador's progress in the last two categories for the improved ranking (IMF, 2018, p.18).

Concerning its competitive ranking in Central America, according to the World Economic Forum's (WEF) Global Competitiveness Index, El Salvador is listed last of six Central American countries included in the index. With respect to its global competitiveness position, El Salvador was ranked 104th out of 137 countries. In particular, the World Economic Forum cited El Salvador's poor labor market efficiency index relative to Central American and Latin American countries, focusing on the high degree of labor market informality and the low participation rate of women in the labor force. According to the IMF (2018), both of these can be addressed only by enhancing the efficiency of Salvadoran institutions, in particular improving the quality of education to foster the nation's stock of "human capital".

Regarding the financial sector, El Salvador has a well-developed and well-established banking sector that is more than $90 \%$ foreign-owned. Despite its high population density rate with respect to population and an urbanization rate approaching $70 \%$ of the population, with only about a third of the population using banks or credit cards, El Salvador provides its population with poor access to financial institutions, impeding financial inclusion. A recent IMF study analyzing the relationship between financial development and economic growth suggests that "relatively less developed countries have a large potential to boost growth by increasing financial development" (IMF, 2016b, p. 71). Therefore, increasing financial inclusion during the next decade could improve the prospects for El Salvador to escape its loworbit growth that has impeded the improvement in living standards.

\section{Global Linkages}

Over the last three years we have witnessed a backlash over globalization that was exemplified by the June 2016 Brexit referendum in the United Kingdom, the victory of Donald Trump in the November 2016 US presidential elections that ushered in the new administration's "America first" trade policies, the new Italian government that was formed in the wake of the March 2018 national elections, and most recently, the gilets jaunes-led protests that rocked France in late 2018. This backlash in developed countries was triggered largely by poorly-managed environmental, immigration, and trade policies that were amplified by the wave of refugees fleeing from war- and violence-torn areas of Africa and the Middle-East, reduced labor force participation rates particularly among the young and unskilled, stagnant wage growth for over 
a decade, and increasing income inequality. However, in the opinion of most economists, adhesion of the national economy to the larger global economy is still indispensable for improving a nation's material well-being. It is without doubt that the successful development model implemented by China over the last four decades is, in part, due to China's re-engagement with the world economy after decades of economic autarky.

Consumers benefit from liberalized trade by having more choice of goods, often at lower prices and/or with higher quality. Greater competition faced by domestic producers from imported goods reduces domestic producers' pricing power, and provides crucial incentives to enhance efficiency and productivity. The prospects of higher exports (in part to pay for increased imports) raise both national employment and income.

Liberalization of the capital account -- provided the domestic banking system is sufficiently strong -along with a unitary and market-based exchange rate, confers benefits to both borrowers and investors alike. Lower interest rates for borrowers, and improved risk/reward tradeoffs for investors, as well as greater discipline in managing the public finances imposed by these open capital markets complement the benefits provided by a liberalized trade account. It is important to note that policy experts are still debating the cost/benefit calculus of full capital account liberalization for developing countries in the wake of the Asian financial crisis at the end of the 1990s and the financial meltdown in the US and Europe a decade later (Beattie, 2011; Plender, 2012). Finally, providing a "state-of-the-art" legal, tax, and regulatory environment for foreign investment is critical for attracting and maintaining much-needed financial capital, new technology, and managerial talent for the national economy.

The main issues discussed in this section focus on El Salvador's integration with the world economy as it adapts the structure of its exports to its changing competitive position in the global economy and as it continues to liberalize its trade regime through tariff reduction and forging bilateral and regional trade agreements. In particular, El Salvador must continuously adjust its domestic economic policies to incorporate its full-dollarization policy, and, most important, the impact of the large (and growing) Salvadoran diaspora that has macro-and micro-economic consequences for the national economy, as well as the potential effects that the decision by the US government to end the Temporary Protection Status program for Salvadorans that was mentioned above. In its Article IV report on El Salvador (IMF, 2018), the IMF describes the possible consequences to El Salvador's economy of enhanced border controls and deportations by the US government of asylum seekers and migrants residing in the US illegally. (More about this below). In addition, this section also addresses the outlook for foreign direct investment, a key ingredient in raising the potential growth rate of the economy that would facilitate an escape from the country's "low-orbit growth" to the end of improving living standards and reducing its poverty rate.

As mentioned above El Salvador's balance of trade has been solidly negative for years. Over the 2012-17 interval, total trade (exports plus imports) as a percent of GDP has averaged about 77\%. However, the import ratio over those seven years averages about $45 \%$, so the result is a large trade deficit, about $20 \%$ of GDP, that has been plugged by massive remittances -- over $\$ 4 \mathrm{bn}$ a year -- from the Salvadoran diaspora, residing (legally and illegally) mostly in the US.

As discussed above, coffee at the end of the 19th century emerged as virtually the sole export crop of El Salvador, displacing indigo. By 2017, coffee accounted for less than $2 \%$ of total exports, while textile exports -- sourced from both from maquila and non-maquila production sites -- comprised almost half of Salvadoran exports. However, El Salvador is now facing stiff competition from emerging Asian economies like Vietnam and Cambodia, in addition to China, India and Bangladesh (IMF, 2018).

Both El Salvador's exports and imports are highly concentrated in the Americas (over $90 \%$ of the former and more than $75 \%$ of the latter), with almost half of total exports going to the US and approximately $40 \%$ of total imports coming from the US (World Trade Organization, 2016). For better or for worse, the source of El Salvador's imports and the destination of its exports demonstrate the outsized influence the "elephant" to the north exercises over the Salvadoran economy even without the issues of migration, remittances and direct foreign investment to be discussed below are taken into account.

In addition to membership in the World Trade Organization (and its precursor institution, GATT), in 2004 El Salvador was the first country to ratify the Central America Free Trade Agreement (CAFTA-DR)

Journal of Applied Business and Economics Vol. 21(7) 2019159 
with the US that came into effect in 2006. As far back as 1960, to enhance regional integration El Salvador was a signatory to the General Treaty on Central American Economic Integration (TGIEC) that created the Central American Common Market (CACM) between Costa Rica, El Salvador, Guatemala, Honduras and Nicaragua. This treaty led to the adoption of a common tariff and the commitment to set up a customs union. Since 2010, El Salvador has negotiated and concluded regional trade agreements (RTAs) with the European Union (EU), Colombia, Cuba, Mexico, and most recently, a free trade agreement (FTA) with South Korea (World Trade Organization, 2016). Finally, El Salvador is moving forward with reforms required for the creation of a proposed customs union with Guatemala and Honduras.

To ensure greater participation in the global economy, in November 2000, the Monetary Integration Law was passed by Salvadoran legislators. The law made the US dollar the legal currency of the country in place of the Salvadoran colon. It is important to note that in contrast to other Latin American countries who have dollarized their economies -- either fully in the case of Ecuador and Panama or incompletely as was done from 1991-2002 in Argentina with its currency board -- El Salvador implemented this reform without the stress of a monetary or balance of payments crisis. During the five years preceding the dollarization of the economy annual inflation was only 3.7\% (Hidalgo, 2009, p. 9).

The main objective to adopt dollarization of the economy was to promote growth. Dollarization "eliminates the risk of devaluation and protects the value of deposits, pensions, and salaries; lowers interest rates; encourages private investment; and minimizes the lack of monetary credibility through the elimination of an independent monetary policy" (Hidalgo, 2009; p. 9). In addition, dollarization has also helped to impose fiscal discipline on the Salvadoran government, since the country no longer has an independent monetary policy.

One wrinkle in this policy that is unique to El Salvador has, at times, undermined its ability to control inflation due to the enormous amount of dollar remittances (see below) that flow into El Salvador every year (almost 20\% of GDP) that increases the money supply, and can fuel inflation. Even though dollarization provides relative price stability if US inflation is low, another downside of a fully dollarized economy is the adverse competitive effect an appreciating US dollar has on Salvadoran exports. A similar outcome results from any large increase in the minimum wage as was the case in late 2016, which was discussed above. It is also important to mention again that El Salvador's trade balance is also very sensitive to the volatility of global oil prices, which are valued in dollars.

Before examining the important role that remittances play in the Salvadoran economy, it is useful to explain the source of these remittances. Out-migration from El Salvador began early by Central American standards. Though the main motive for emigration has always been economic, the long and devastating civil war in the 1980s triggered enhanced emigration from El Salvador, principally to the United States. Following a pair of earthquakes in 2001, as a humanitarian gesture, the US government extended protections to some 200,000 Salvadorans who were legally residing in the US at that time through its Temporary Protection Status program (TPS). Foreign nationals with TPS protections are generally able to obtain work authorization and a driver's license, but the TPS designation is subject to US government review and can only be extended for up to 18 months, although the secretary of homeland security can extend TPS protections as a result of ongoing armed conflict, an environmental disaster, or "other extraordinary and temporary conditions (Miroff, 2018). All subsequent US administrations renewed the TPS designation every 18 months until the Trump administration ended the program in January, 2018. Salvadorans are by far the largest group of TPS holders. As was mentioned above, in October 2018, a federal judge issued a restraining order on implementing the Administration's order pending a judicial review.

Over the years, as a result of "family unification" programs, "networking" among prospective emigres and Salvadoran nationals residing in the US, and, most recently, gang-related crime and violence, the number of Salvadorans residing -- legally and illegally -- in the US has swelled to $1.4 \mathrm{~m}$ people (about $20 \%$ of El Salvador's population), of which an estimated 55\% are unauthorized immigrants (Cohn, Passel \& González-Barrera, 2017). According to the United Nations, for the last 40 years El Salvador has had the highest emigration rate in Central America (IMF, 2016b, p.13). 
Given the extent of emigration from El Salvador, it is large enough to have demographic and economic consequences. Specifically, large scale emigration from a small country lowers the country's population growth rate -- El Salvador has the lowest population growth rate in Central America -- and since emigration is largely dominated by young people who are among the most productive and flexible part of a nation's labor force, the migration of Salvadorans to the US over the last 40 years has affected not only the size of the labor force, i.e., the supply of labor, but also its skill level, that is, its productivity (IMF, 2016b, p.13). Both of these are essential "ingredients" for economic growth and rising living standards. While it is uncertain at this time how many of the recipients of the TPS program will be repatriated to El Salvador, there is even greater uncertainty regarding how many of the estimated 800,000 illegal Salvadoran immigrants will be deported as a result of the Trump administration's crack-down on illegal immigration and asylum seekers.

Turning to remittances, according to a Pew Research Center (2018) analysis of World Bank data, the three Northern Triangle countries were among the top 10 estimated remittance-receiving nations from immigrants in the US in 2015. In 2017, according to World Bank estimates, remittances to the three nations totaled $\$ 17.9$ billion, of which most came from the US. In 2017, according to the World Bank, remittances were the equivalent of about $20 \%$ of GDP in El Salvador ( $\$ 5.1 \mathrm{bn}), 11 \%$ in Guatemala (\$8.5bn), and $19 \%$ in Honduras $(\$ 4.3 \mathrm{bn})$.

According to the IMF (2016a, p.14), remittances are an important source of private sector income for Northern Triangle countries. For El Salvador, the dollar amount of annual remittances dwarf FDI flows (to be discussed below) and, in 2017, remittances reached about $75 \%$ of the value of total exports. By supporting consumption, the IMF argues, remittances play a positive role for short-term economic growth, but its "flip-side", migration -- the "export" of mainly young people, often permanently -- has negative implications for the long-term growth potential of the economy, as mentioned above.

This said, the IMF (2018, p. 9) estimates that annual remittances from the 200,000 current beneficiaries of the TPS program for Salvadorans are equivalent to approximately $2.5 \%$ of annual Salvadoran GDP, and, if repatriated, will increase the Salvadoran population by approximately 3\%. Redeploying these returning nationals into the domestic labor force will present challenges in the shortterm. However, most analysts believe that only a small number of these $200,000+$ emigres will eventually return to El Salvador since many are expected to be regularized by the September 2019 deadline to leave the US, absent a more aggressive US enforcement policy. The "wild card", of course, for the Salvadoran economy is the level of deportations by the US authorities of illegal non-TPS Salvadoran nationals over the next few years.

Foreign direct investment is an important ingredient in modernizing and increasing the efficiency and growth potential of developing countries' economies. Indirectly, it also supports lowering a country's poverty rate and reducing income inequality. Between 2012-2017, according to the World Bank, foreign direct investment (FDI) flows to El Salvador were almost never more than \$500m a year (that is, the FDI to GDP ratio was below 2\% of GDP)! According to the International Monetary Fund, El Salvador had the lowest ratio of FDI to GDP in Central America for the five years ending in 2015. For purposes of comparison, Panama's ratio was approximately 10\% of GDP, the highest in the region (IMF, 2016, p. 19).

Foreign direct investment in El Salvador is concentrated mainly in four sectors: finance, manufacturing, telecommunications, and the electricity sector (World Trade Organization, 2016). The US share of total foreign investment in El Salvador is approximately 30\%. However, El Salvador is unlikely to be the destination of higher foreign investment flows without introducing structural reforms that include major initiatives to reduce the level of crime and violence, contain future minimum wage increases to maintain international competitiveness, ease barriers to competition that would enhance the entry of foreign firms into the domestic economy, and boost educational attainments to improve the nation's stock of human capital, one of the subjects discussed in the next section.

\section{An Active Government Policy to Promote Social and Economic Investment}

The last of the four World Bank "ingredients" to be included in the recipe for a well-managed national economy is an active government policy that promotes social and economic investment, 
especially in the areas of poverty reduction, health, education, and physical infrastructure, including transport, telecommunications, and energy. For many of the world's countries during most of the second half of the 20th century rapid economic growth led to increased living standards that were accompanied by marked improvements in public health systems, nutrition, greater access to education, and, as a result of these, significant increases in life expectancy and reductions in infant mortality and adult morbidity rates (Gordon, 2016; Ip, 2019).

The United Nations Development Programme in its Human Development Report 2016 (UNDP, 2016) ranked El Salvador $117^{\text {th }}$ out of 188 reporting countries in its key metric, the Human Development Index. For the purposes of comparison with its neighbors, Guatemala ranked 125th, Honduras, 130th and Nicaragua, 124th. The index measures the average achievement in three basic dimensions of human development: life expectancy; education levels; and the standard of living (measured by GDP per capita).

The World Bank's Worldwide Governance Indicators (WGI) are a research dataset summarizing the views on the quality of governance provided by enterprise, citizen, and expert survey respondents in industrial and developing countries. These data are gathered from a number of survey institutes, think tanks, non-governmental organizations, international organizations, and private sector firms. The WGI report country percentile rankings against the world (and various regions) of six measures of "good government".

For 2016, in all six categories (voice and accountability; political stability and absence of violence; the rule of law; control of corruption; government effectiveness; and regulatory quality) El Salvador's ranking was below (and for some, significantly below) the rankings of Costa Rica and Panama as might be expected, but ranked higher than its immediate "neighbors" in Central America (Guatemala, Honduras, and Nicaragua) in all six categories of governance. Since 2006 marginal improvements have been recorded in three of the categories: voice and accountability; political stability and absence of violence; and regulatory quality; while in the remaining three categories -- political stability, the rule of law, and control of corruption -- El Salvador's ranking in 2016 was below its ranking of a decade earlier.

Complementing the WGI is the ranking established by Transparency International, which has chapters in over 100 countries with an international secretariat in Berlin which works with governments, businesses, and citizens to stop the abuse of power, bribery and secret deals. El Salvador's ranking in Transparency International's 2017 "Corruption Index"-- 112th out of 180 countries -- though above its immediate regional "neighbors" Guatemala, Honduras, and Nicaragua -- testifies to the high degree of corruption, the lack of transparency and accountability in government, and the weak rule of law, not only in El Salvador but throughout Central America, with the exception of Costa Rica.

In September 2000, building upon a decade of major United Nations conferences and summits, world leaders came together at the United Nations Headquarters in New York to adopt the United Nations Millennium Declaration. The Declaration committed nations to a global partnership to reduce extreme poverty, and set out a series of eight time-bound targets -- with a deadline of 2015 -- that have become known as the Millennium Development Goals (MDGs). Many of the aid programs -- with multilateral institutions such as the World Bank and the International Monetary Fund and bilateral programs with individual countries -- with which El Salvador has participated are structured around these MDG goals. Therefore, the remainder of this section highlights the progress made by El Salvador in meeting these MDG targets.

According to the World Bank, El Salvador's poverty rate, based on its national poverty line, was virtually unchanged -- from $40 \%$ of the population in 2008 at the inception of the global financial crisis to $38.2 \%$ in 2016 -- though it declined appreciably from a rate of $60 \%$ during the final years of the civil war (IMF, 2018, p. 24). However, over the 2008 - 2012 interval there was a 50\% decline in the percentage of the population that is living in extreme poverty, from $4.8 \%$ to $2.5 \%$. While El Salvador's poverty rate is in the middle range for Central American countries (Table 1), this persistently high rate also seems to be a casualty of El Salvador's low-orbit growth rate, discussed above. Without a consistently higher growth trajectory it is unreasonable to expect that the national poverty rate can be reduced in a sustainable way.

One of the demographic variables that is critical to improving living standards in developing countries over the long-term is the total fertility rate (the number of children per woman). During the last 
half century El Salvador has made considerable progress -- along with its regional neighbors -- in reducing its total fertility rate. Over the 1970-75 interval El Salvador's fertility rate was 5.9 as compared with 6.5 for the Central American region as a whole, and for the 2010-15 interval, El Salvador's fertility rate declined to 2.0 children per woman, below the regional average of 2.4 children per woman.

One of the important metrics that contributes, over the long-term, to lowering the national fertility rate is a country's infant mortality rate (number of deaths per 1,000 live births). The world-wide improvement in this metric over the last half century is one of the great achievements that can be credited to modern medicine combined with successful public health initiatives: in 1966, the rate in El Salvador was 113.4, while half a century later the rate declined monotonically to 12.9 , a rate that was even below the Latin America and Caribbean average of 14.9. Although the infant mortality rate in the United States is less than half the rate in El Salvador, in percentage terms the decline over the 50 year interval in El Salvador was greater than in the US.

Achieving universal primary education is another of the United Nations' stated Millennium Development Goals. Over the last half century El Salvador has made considerable progress in addressing this important goal which has implications for the skill level and productivity of its labor force. In 1970 the primary school completion rate was $40.5 \%$ (for the relevant age group) that steadily increased throughout the period of the civil war reaching 62.3\% in 1991, and by 2011 the country had achieved universal primary education. However, by 2016, the rate receded to $93 \%$, likely the result of the intensified violence and gang-instilled fear that is affecting the Salvadoran population, especially its younger -- and more vulnerable -- cohort. A similar pattern can be observed with Guatemala, another "conflict" area: its rate increased from $22 \%$ in 1970 to $92.5 \%$ in 2015 , only to revert back to $82.7 \%$ in 2016. Despite the improved primary school completion rate it is important to note that nothing in the data presented mentions anything about the "quality" of the education, an issue raised in the discussion on improving the productivity of El Salvador's labor force in the IMF's Article IV report (IMF, 2018, p. 18). Finally, a primary school education -- even a quality one -- is unlikely to instill the skills needed for a labor force engaged in a globalized 21st century economy: only half of Salvadoran youth attend junior high school, and only half of those complete high school (Markham, 2018).

Turning to some MDG's which affect the "quality of life", $80 \%$ of the population had access to basic drinking water services in 1990 -- as compared to the regional average of $90.5 \%$-- with the percentage increasing to $93 \%$ a quarter of a century later, converging towards the regional average of $96 \%$. Concerning sanitation services, $82 \%$ of the population had access to basic sanitation services in 1990 compared with $75 \%$ in the region, and by 2015 , over $90 \%$ of Salvadorans had access to basic sanitation services, above the regional average of $86 \%$. Judging by the above data it appears that El Salvador has made steady progress over the last quarter of a century in providing its population access to these two essential "quality of life" amenities.

Regarding the provision of physical infrastructure -- electricity, transport, and communications -which simultaneously increases the efficiency of the economy and confers "quality of life" benefits to residents, there has been progress in this area as well. From 1990 to 2014, annual per capita electricity consumption (in $\mathrm{kWh}$ ) in El Salvador increased from 353 to 939, an annualized growth rate of 4.0\%, compared with the Latin America and Caribbean region, where per capita electricity consumption increased from 1168 to $2129 \mathrm{kWh}$ over the same interval, an annual rate of increase of $2.4 \%$. In 2013, about $94 \%$ of the population had access to electricity (CIA, 2018), the second highest rate in Central America after Costa Rica. El Salvador's transport infrastructure viewed through the lens of paved roads is "miles" ahead of its regional neighbors. In 2016, almost two-thirds of El Salvador's roads were paved. The corresponding metric for Nicaragua was 14\%; Costa Rica, 26\%, Guatemala, 43\% and the United States, 65\% (CIA, 2018).

Turning to communications infrastructure, with regard to the percentage of Salvadorans using the internet, in 2016 only $29 \%$ of the population reported using the internet, the second lowest percentage in Central America, just above Nicaragua's rate of 25\% (CIA, 2018). In 2016, per 100 of population, Salvadorans had 15.0 fixed telephone subscriptions with an average in the Latin America region of 17.4 telephone subscriptions. The corresponding metrics for the United States were 76.2 internet users and 
38.4 fixed line subscriptions in 2016. It is important to point out that as a result of the introduction and rapid adoption of cellular phones, fixed telephone subscriptions in the US peaked at 68 in 2000, and the rate is receding in both El Salvador and the Latin America and Caribbean region, both also peaking at about 18 in 2008. Mobile cellular subscriptions (per 100 of population) in El Salvador were 156 in 2016, above the penetration rates of both the US and the Latin America and Caribbean region.

The last two components in the World Bank's fourth "ingredient" was expanded to include the "second tier" reforms (World Bank, 1997) -- public security and governance -- that affect the quality of life directly, and the economy, indirectly. Drugs-related activities, poverty and insufficient economic opportunities (especially for young people) breed insecurity, kidnapping, theft, murder, extortion, and corruption (discussed above), all, regrettably, in abundance in Central America in general, and in the Northern Triangle countries in particular. According to the United Nations Development Program, Latin America is the only region in the world where the murder rate increased from 2000-10 (The Economist, 2014), and the isthmus of Central America, as mentioned earlier, is considered to be the "most routinely murderous region on earth" (The Economist, 2011).

That said, although the homicide rate of 82.8 in 2016 that appears in Table 1 receded by almost $20 \%$ from its 2015 rate of 105.4, over the last five years the rate has doubled! With the general lack of security in El Salvador and the other Northern Triangle countries it is not an exaggeration to say these countries are becoming "failed states", and it is not surprising that El Salvador has had the highest emigration rate in Central America for the last four decades, as mentioned above. Most of the migrants participating in the "caravans" attempting to enter the US through the border with Mexico in the Fall 2018 - Winter 2019 were nationals from the Northern Triangle countries.

It is interesting to compare El Salvador's homicide rate with the rate in Nicaragua, given that per capita GDP in El Salvador is 50\% above that of Nicaragua. (Please see Table 1, above). While Nicaragua, using per capita GDP (ppp), is the second poorest country in Central America it has the lowest homicide rate, even below the rates for Costa Rica and Panama, which have much higher levels of per capita income (Table 1, above). While many associate crime with poverty, Nicaragua appears to have severed that relationship. Of course, it will be interesting to monitor any changes in the homicide rates in Nicaragua over the next few years in light of the civil unrest plaguing the country since the spring of 2018.

Experts attribute the lower level of overall violence in Nicaragua -- relative to its neighbors -- to the policy of "community policing" which is practiced by the National Police, an institution that is a product of the 1979 Sandinista revolution and the subsequent civil war. According to The Economist (2014), "instead of mano dura -- the iron-fist policies of its northern neighbors -- it offers a 'friendly hand' to prevent gang penetration in Nicaraguan society. After Mexico's former President Felipe Calderón declared war on drugs in 2006, Mexico began squeezing its cartels at home, and the drug-related violence moved south, transforming Central America from a passive transit route into a central theater in the war on drugs.

Honduras, El Salvador, Guatemala and Belize responded by militarizing their response with funding and training from United States, under a program called the Central American Regional Security Initiative (CARSI). Nicaragua, in part because of its tense relations with the United States in the wake of the civil war in the 1980s, was not included in this program, forcing it to choose a different path.

\section{CONCLUSION}

Over the last quarter century political leaders and policymakers in virtually every country in the world have been confronted with the same question: In the wake of widespread political, technological, and institutional change around the world, for countries that are firmly anchored in the global economy of the 21 st century, what adjustments are required in a country's economic and financial policies that will lead to improvements in material wellbeing for the population at large? From China to Brazil, Russia to South Africa, Japan to Australia, India to North Africa, and, even from the United States to Western Europe, all have struggled, or are struggling, with the same "existential" problem: how can countries increase -- or, in 
the worst case, maintain -- living standards for the bulk of their populations, given the "cards they have been dealt"?

The objective of this paper is to present the predicament of El Salvador, a middle-income country that is located, on the one hand, in one of the most violent regions of the world and, on the other, at the crossroads of today's global economy: near the southern rim of the large and wealthy North American continent and near the northern boundary of the equally large though much less prosperous South American landmass. Unlike all the other countries of Central America (except Belize) which have sovereign access to both the Atlantic and Pacific Oceans, El Salvador has access only to the Pacific Ocean.

Even with its relatively low-wage (and, to be sure, low-skilled, even by Asian standards) labor force, can El Salvador confront its endemic institutional failures characterized by chronic violence, widespread corruption, the absence of the rule of law, poor governance, along with increasing physical and economic insecurity which combine to deter foreign investment on the one hand, and on the other, encourage the country's talented young people to seek better lives through migration (often illegally to the US), that effectively retards improvements in material well-being for its predominantly poor population? As this paper has argued, it appears that El Salvador is descending into the status of a "failed state", and that the above mentioned problems will need to be addressed by an international -- or, at the least, by a regional - response, since the recent national programs to come to grips with the increasingly intractable institutional failures all appear to be inadequate.

\section{ACKNOWLEDGEMENTS}

I thank Claudia Binaghi for her great help in creating the tables that appear in the paper and the attractive PowerPoint presentation slides used at the Conference.

I am grateful to the Department of Economics and the School of Business at Montclair State University, who jointly provided the required funding to enable me to present the paper at the Twentieth

Annual Conference of the National Business and Economics Society, in March 6-9, 2019 in San Juan, Puerto Rico.

\section{REFERENCES}

Acemoglu, D., \& J. Robinson. (2012). Why Nations Fail: The Origins of Power, Prosperity, and Poverty. New York: Crown Business.

Ahmed, A. (2017). They Will Have to Answer to Us. The New York Times Magazine, December 3.

Arce, A. (2016). El Salvador Throws Out Gang Truce and Officials Who Put It in Place. The New York Times, May 21.

Balassa, B., \& Associates. (1971). The Structure of Production in Developing Countries. Baltimore and London: Johns Hopkins Press.

Basic Drinking Water Services (Percent of Population). (n.d.). Retrieved from https://data.worldbank.org/indicator/SH.H2O.BASW.ZS?locations=ZJ-SV

Basic Sanitation Services (Percent of Population). (n.d.). Retrieved from https://data.worldbank.org/indicator/SH.STA.BASS.ZS?locations=ZJ-SV

Beattie, A. (2000). World Bank Stages Intellectual Battle over Globalization. Financial Times, June 30.

Beattie, A. (2011). Tension Over Capital Flows Draws IMF Into the Fray. Financial Times, January 6.

Bhagwati, J. (1978). Foreign Trade Regimes and Economic Development: Anatomy and Consequences of Exchange Control Regimes. Cambridge, MA: Ballinger Press.

Blitzer, J. (2018). Trapped. The New Yorker, January 1.

Central Intelligence Agency. (CIA). (2018). The World Factbook, (n.d.). Retrieved from https://www.cia.gov/library/publications/the-world-factbook/geos/pm.html

China's Alarming Debt. (2018, April 3). Retrieved from https://www.bloomberg.com/news/articles/201804-03/china-s-alarming-debt-pile-seen-finally-stabilizing-this-year 
Cohn, D., Passel, J., \& González-Barrera, A. (2017, December 7). Retrieved from http://www.pewhispanic.org/2017/12/07/rise-in-u-s-immigrants-from-el-salvador-guatemala-andhonduras-outpaces-growth-from-elsewhere/

Commission on Growth and Development. (2008). The Growth Report: Strategies for Sustained Growth and Inclusive Development. Washington, D.C.

Corruption Index. (n.d.). Retrieved from https://www.transparency.org/country/\#SLV

Data. World Bank. (n.d.). Retrieved from http://data.worldbank.org

De Córdoba, J. (2018). Migration Barely Figures in Mexico Vote. The Wall Street Journal, June 27.

Dreier, J. (2019). The Disappearing Boys of Huntington High. The New York Times Magazine, January 6.

El Salvador. (2018, December 1). Retrieved from https://en.wikipedia.org/wiki/El_Salvador

El Salvador Population. (n.d). Retrieved from http://worldpopulationreview.com/countries/el-salvadorpopulation/

Exports of Goods and Services. (n.d.). Retrieved from https://data.worldbank.org/indicator/NE.EXP.GNFS.CD?locations $=\mathrm{SV}$

Financial Times. (2016). China's Addiction to Debt Threatens the Economy, September 20.

Football War. (2018, December 26). Retrieved from https://en.wikipedia.org/wiki/Football_War

Foreign Direct Investment (Net Flows). (n.d.). Retrieved from https://data.worldbank.org/indicator/BX.KLT.DINV.CD.WD?locations $=\mathrm{SV}$

Forero, J. (2018). Latin America Turns Deadly for Women. The Wall Street Journal, December 20.

GDP Growth in US and El Salvador (Annual Percent). (2018, December 31). Retrieved from https://data.worldbank.org/indicator/NY.GDP.MKTP.KD.ZG?locations=SV-US

Gordon, R. (2016). The Rise and Fall of American Growth: The U.S. Standard of Living Since the Civil War. Princeton and Oxford: Princeton University Press.

Gross Domestic Product (annual percentage growth). (n.d.). Retrieved from https://data.worldbank.org/indicator/NY.GDP.MKTP.KD.ZG?end=2016\&locations=SV\&name_ desc $=$ false\&start $=1992$

Gross Capital Formation (Percent of GDP): China. (2018, December 31). Retrieved from (https://data.worldbank.org/indicator/NE.GDI.TOTL.ZS?locations $=$ CN\&view $=$ chart

Hannon, P., \& J. Zumbrun. (2018). Global Slowdown Sparks Worries About U.S. Strength. The Wall Street Journal, December 15.

Hausmann, R., Klinger, B., \& Wagner, R. (2008). Doing Growth Diagnostics in Practice: A 'Mindbook'. Harvard University Center for International Development Working Paper 177, September.

Hausmann, R., Rodrik, D., \& Velasco, A. (2008). Growth Diagnostics (Chapter 15), in The Washington Consensus Reconsidered: Towards a New Global Governance, Eds. J. Stiglitz and N. Serra, New York: Oxford University Press.

Heritage Foundation. (2018). El Salvador. Retrieved December 31, 2018, from https://www.heritage.org/index/country/elsalvador

Hidalgo, J.C. (2009). El Salvador: A Central American Tiger? Center for Global Liberty \& Prosperity, Cato Institute, March 9.

Imports of Goods and Services as a Percentage of GDP. (n.d.). Retrieved from https://data.worldbank.org/indicator/NE.IMP.GNFS.ZS?locations $=\mathrm{SV}$

Inflation in Venezuela. (n.d.). Retrieved from https://blogs.imf.org/2018/07/23/outlook-for-the-americasa-tougher-recovery/

Infant Mortality Rates (per 1000 Live Births). (n.d.). Retrieved from https://data.worldbank.org/indicator/SP.DYN.IMRT.IN?locations=ZJ

Infrastructure. (n.d.). Retrieved from http://data.worldbank.org/topic/infrastructure?locations=ZJ-SV

Intentional Homicides. (n.d.). Retrieved from https://data.worldbank.org/indicator/VC.IHR.PSRC.P5?locations=SV-AE\&view $=$ chart

Intentional Homicide Victims. (n.d.). Retrieved from https://dataunodc.un.org/crime/intentionalhomicide-victims

166 Journal of Applied Business and Economics Vol. 21(7) 2019 
International Monetary Fund (IMF). (2016a). El Salvador, Staff Report For The 2016 Article IV

Consultation. June, Washington, D.C.

International Monetary Fund (IMF). (2016b). El Salvador, Selected Issues, July, Washington, D.C.

International Monetary Fund (IMF). (2018). El Salvador, Staff Report For The 2016 Article IV

Consultation, April. Washington, D.C.

Ip, G. (2019). The World Is Quietly Getting Better. The Wall Street Journal, January 3.

Jelmayer, R., \& J. Lewis. (2016). Brazil's Economic Gloom Lightens. The Wall Street Journal, July 25.

Jordan, M. (2018). U.S. Eliminates A Protected Visa For Salvadorans. The New York Times, January 9.

Kristhof, N. (2016). Deporting Kids to Die, Sunday Review. The New York Times, July 17.

Krueger, A. (1978). Foreign Trade Regimes and Economic Development: Liberalization Attempts and Consequences. MA: Ballinger Press.

Kurmanaev, A. (2018). The Tragedy of Venezuela. The Wall Street Journal, May 26.

Kynge, J. (2016). Investors' Taste for China Sours Over Debt Fears. Financial Times, September 2.

Latin America and the Caribbean Population. (n.d.). Retrieved from www.worldometers.info/worldpopulation/latin-america-and-the-caribbean-population/

Latin America and the Caribbean: Annual Growth in Gross Domestic Product, 2011-2017. (2018, December 31). Retrieved from http://repositorio.cepal.org/bitstream/handle/11362/40826/62/S1601332_en.pdf, Table VII.

Latin America and The Caribbean: Regional Economic Profile. (n.d.). Retrieved from $\mathrm{http}$ //estadisticas.cepal.org/cepalstat/Perfil_Regional_Economico.html?idioma=english

Little, I., Scitovsky, T., \& M. Scott. (1970). Industry and Trade in Some Developing Countries. London: Oxford University Press.

Lobo-Guerrero, C. (2017). In El Salvador, 'Girls Are a Problem'. The New York Times, September 3.

Long, G. (2018). Trust is the New Currency in the Surreal Caracas Economy. Financial Times, May 29.

Madrick, J. (2018). Staying the Invisible Hand. The New York Review of Books, June 28, 44-6.

Mahalanobis, P. (1955). The Approach to Operations Research to Planning in India. The Indian Journal of Statistics, 16(1/2), 3-62.

Magnier, M., \& Cui, C. (2017). Moody's Gives China a Warning, The Wall Street Journal, May 25.

Malkin, E., \& Arce, A. (2016a). Indigenous Activist in Honduras Killed, The New York Times, March 4.

Malkin, E. (2018). El Salvador Avoids Vote to Soften Abortion Plan. The New York Times, April 27.

Mander, B. (2018). Copper Price Fall Sparks Fears for Pace of Chile Reform Program. Financial Times, July 31.

Markham, L. (2018). No Place for 200,000 People to Go, OP-ED. The New York Times, January 14.

Martínez, O. (2013). Making a Deal with Murderers. The New York Times, October 6.

Martínez, O., Lemus, E., Martínez, C., \& Sontag, D. (2016). Tin-Cup Gangs of El Salvador. The New York Times, November 21.

MDG Progress Status. (n.d.). Retrieved from http://datatopics.worldbank.org/mdgs/compare-trends-andtargets-of-each-mdg-indicator.html

Miroff, N. (2018, January 8). Retrieved from https:/www.washingtonpost.com/news/worldviews/wp/2018/01/09/what-is-tps-and-what-willhappen-to-the-200000-salvadorans-whose-status-isrevoked/?noredirect $=$ on\&utm term $=$. a0dc $42931 \mathrm{~d} 5 \mathrm{e}$

Mokyr. J. (2017). A Culture of Growth: The Origins of the Modern Economy. Princeton and Oxford: Princeton University Press.

New York Times. (2016). Seeking Justice in El Salvador, July 23.

O'Grady, M. (2016a). El Salvador's Market Economy Under Siege. The Wall Street Journal, April 25.

O'Grady, M. (2016b). A Salvadoran Lesson for Colombia, August 1.

Palumbo, G., \& Ahmed, A. (2018). El Salvador Feels the Weight of Washington Shaping Its Fate. The New York Times, January 10. 
Pew Research Center. (2018, January 23). Retrieved from http://www.pewglobal.org/interactives/remittance-map/

Personal Remittances. (n.d.). Retrieved from https://data.worldbank.org/indicator/BX.TRF.PWKR.CD.DT?locations $=\mathrm{SV}$

Personal Remittances (Percent of GDP). (n.d.). Retrieved from https://data.worldbank.org/indicator/BX.TRF.PWKR.DT.GD.ZS?locations=SV

Plender, J. (2012). Growth Targets Risk Currency Wars and Capital Controls, Insight. Financial Times, December 19.

Poverty Headcount Ratio at National Poverty Lines (Percent of Population). (n.d.). Retrieved from https://data.worldbank.org/indicator/SI.POV.NAHC?locations $=$ SV\&view=chart

Prebisch, R. (1959). Commercial Policy in the Underdeveloped Countries. American Economic Review, 49(2), 251-73.

Primary Completion Rate, Total (Percent of Relevant Age Group). (n.d.). Retrieved from https://data.worldbank.org/indicator/SE.PRM.CMPT.ZS?locations=SV-GT

Rao, P., \& Ewing, J. (2017). E.U. and Japan Reach Deal to Keep 'Flag of Free Trade' Waving High. The New York Times, December 9.

Rathbone, J. (2016). Under New Management, FT Big Read, Latin America. Financial Times, June 23.

Rathbone, J. (2018). 21st Century Socialism Unravels in Venezuela, Cuba, and Nicaragua. Financial Times, June 12.

Roberts, S. (2017). Armando Calderón Sol, Who Led El Salvador, Dies at 69. The New York Times, October 11.

Rocca, F.X. (2018). Pope Elevates a New Saint. The Wall Street Journal, October 15.

Rodrik, D. (2010). Diagnostics Before Prescription. The Journal of Economic Perspectives, 24(3), Summer.

Rodrik, D. (2018). Straight Talk on Trade: Ideas for a Sane World Economy. Princeton: Princeton University Press.

Rosenstein-Rodan, P. (1943). Problems of Industrialization in Eastern and South-Eastern Europe. Economic Journal, (53), 202-11.

Runciman, D. (2018). China's Challenge To Democracy. The Wall Street Journal, April 28.

Singer, H. (1964). International Development: Growth and Change. New York: McGraw- Hill.

Soccer War. (2018, July 27). Retrieved from https://adst.org/2014/06/the-1969-soccer-war

Sohn, I. (2008a). Minerals-Supply Security and Minerals-Use Efficiency: Some Observations from the 1970-2005 Interval. Minerals and Energy, 145-61.

Sohn, I. (2008b). Energy-Supply Security and Energy-Intensity: Some Observations from the 1970-2005 Interval. Minerals and Energy, 184-87.

The Economist. (2003). Wanted: A New Regional Agenda for Economic Growth, April 26.

The Economist. (2011). The Tormented Isthmus: Central America, April 16.

The Economist. (2014). Crime in Latin America: A Broken System, July 12.

The Economist. (2015a). Crime in El Salvador: The Broken-Truce Theory, January 31.

The Economist. (2015b). Violence in El Salvador: Rivers of Blood, October 10.

The Economist. (2016a). Human Rights in El Salvador: Digging for Justice, January 2.

The Economist. (2016b). Crime in El Salvador: The Gangs That Cost 16\% of GDP, May 21.

The Economist. (2016c). Coming Clean: China's Debt, July 9.

The Economist. (2017). El Salvador: Unhappy Anniversary, January 21.

The Economist. (2018a). Venezuela's "Crypto-Currency": A Sunny Place for a Shady Currency, March 17.

The Economist. (2018b). Solving Murders, April 7.

The Economist. (2018c). Central America: A Brief Prosecutorial Golden Age, May 12.

The Economist. (2018d). Economic and Financial Indicators, December 22.

Trade as a percent of GDP. (n.d). Retrieved from

https://data.worldbank.org/indicator/NE.TRD.GNFS.ZS?locations $=\mathrm{SV}$

168 Journal of Applied Business and Economics Vol. 21(7) 2019 
United Nations. (1998). Preliminary Overview of the Economies of Latin America and the Caribbean. Santiago, Chile: CEPAL.

United Nations. (2013). Preliminary Overview of the Economies of Latin America and the Caribbean, 2012. Santiago, Chile: CEPAL.

United Nations. (2014). Preliminary Overview of the Economies of Latin America and the Caribbean, 2013. Santiago, Chile: CEPAL.

United Nations. (2015). Preliminary Overview of the Economies of Latin America and the Caribbean, 2014. Santiago, Chile: CEPAL

United Nations. (2016). Preliminary Overview of the Economies of Latin America and the Caribbean, 2015. Santiago, Chile: CEPAL.

United Nations. (2017). Preliminary Overview of the Economies of Latin America and the Caribbean, 2016. Santiago, Chile: CEPAL.

United Nations Development Programme (UNDP). (2016). Human Development Report 2016: Human Development for Everyone, New York: United Nations Development Programme.

Urbanization in Latin America. (2018, December 31). Retrieved from http://www.atlanticcouncil.org/publications/articles/urbanization-in-latin-america

Washington Office on Latin America. (2018). (n.d.). Retrieved from $\mathrm{http} / / / \mathrm{www} . w o l a . o r g / c o m m e n t a r y / f i v e$ facts_about_migration_from_central_america_s_northern triangle

Webber, J., \& Rathbone, J. (2018). Nicaragua Unrest Underscores Frustration with Region's Entrenched Elites. Financial Times, April 26.

Williamson, J. (1994). The Political Economy of Policy Reform, Washington, D.C.: Institute for International Economics.

Williamson, J. (2003). From Reform Agenda to Damaged Brand Name. Finance and Development, September, 10-13.

World Bank. (1991). World Development Report, 1991. New York: Oxford University Press.

World Bank. (1997). World Development Report, 1997. New York: Oxford University Press.

World Bank. (2018). Doing Business. (December 31, 2018). Retrieved from $\mathrm{http}: / /$ doingbusiness.org/rankings

World Economic Forum. (2018). Global Competitiveness Index. (n.d.). Retrieved from reports.weforum.org/global-competitiveness-index/competitiveness-rankings/

World Fertility Patterns, 2015. (n.d.). Retrieved from http://www.un.org/en/development/desa/population/publications/pdf/fertility/world-fertilitypatterns-2015.pdf

World Trade Organization. (2016, August). Trade Policy Review. Retrieved December 31, 2018 from https://www.wto.org/english/tratop_e/tpr_e/s344_e.pdf

Worldwide Governance Indicators. (n.d.). Retrieved from http://info.worldbank.org/governance/wgi/index.aspx\#countryReports 